\title{
UK Renal Registry 14th Annual Report: Chapter 1 UK RRT Incidence in 2010: National and Centre-Specific Analyses
}

\author{
Julie Gilg ${ }^{\mathrm{a}}$, Clare Castledine ${ }^{\mathrm{a}}$, Damian Fogarty ${ }^{\mathrm{ab}}$ \\ ${ }^{a}$ UK Renal Registry, Bristol, UK; ${ }^{b}$ Queens University, Belfast, UK
}

\section{Key Words}

Acceptance rates - Comorbidity - Dialysis - End stage renal disease - End stage renal failure - Established renal failure - Haemodialysis - Incidence - Peritoneal dialysis - Primary Care Trust - Renal replacement therapy - Transplantation . Treatment modality

\begin{abstract}
Introduction: This chapter describes the characteristics of adult patients starting renal replacement therapy (RRT) in the UK in 2010 and the incidence rates for RRT in Primary Care Trusts and Health Boards (PCT/HBs) in the UK. Methods: The basic demographics and clinical characteristics are reported on patients starting RRT from all UK renal centres. Presentation time, defined as time between first being seen by a nephrologist and start of RRT, was also studied. Age and gender standardised ratios for incidence rates in PCT/HBs were also calculated. Results: In 2010, the incidence rates in the UK and England were similar to 2009 at 107 per million population (pmp). The incidence
\end{abstract}

rate fell in Scotland (from $104 \mathrm{pmp}$ to $95 \mathrm{pmp}$ ), increased in Northern Ireland (from $88 \mathrm{pmp}$ to $101 \mathrm{pmp}$ ) and Wales (from $120 \mathrm{pmp}$ to $128 \mathrm{pmp}$ ). There were wide variations between PCT/HBs in standardised incidence ratios. The median age of all incident patients was 64.9 years (IQR $51.0,75.2$ ). For transplant centres this was 63.1 years (IQR 49.7, 74.2) and for non-transplanting centres 66.5 years (IQR 52.9, 76.0). The median age for non-Whites was 57.1 years. Diabetic renal disease remained the single most common cause of renal failure (24\%). By 90 days, $68.3 \%$ of patients were on haemodialysis, $18.1 \%$ on peritoneal dialysis, $7.7 \%$ had had a transplant and $5.9 \%$ had died or stopped treatment. The mean eGFR at the start of RRT was $8.7 \mathrm{ml} /$ $\min / 1.73 \mathrm{~m}^{2}$ which was similar to the previous three years. Late presentation ( $<90$ days) fell from $28.2 \%$ in 2005 to $20.6 \%$ in 2010 . There was no relationship between social deprivation and presentation pattern. Conclusions: Incidence rates have plateaued in England over the last five years. They have fallen in Scotland and fallen and then risen again in Northern Ireland and Wales. Wales continued to have the highest incidence rate of the countries making up the UK. 


\section{Introduction}

This chapter contains analyses of adult patients starting renal replacement therapy (RRT) in the UK in 2010. It describes regional and national variations in incidence rates of RRT, the demographics and clinical characteristics of all patients starting RRT and those presenting late. The methodology and results for these analyses are discussed in three separate sections.

\section{Definitions}

The definition of incident patients is given in detail in appendix B: Definitions and Analysis Criteria (www. renalreg.com/report-area/report 2011/appendix-B.pdf). In brief, it is all patients over 18 who commenced RRT in the UK in 2010 and who did not recover renal function within 90 days: this does not include those with a failed renal transplant who return to dialysis (as they started RRT with or before the transplant).

Differences may be seen in the 2005 to 2009 numbers now quoted when compared with previous publications because of retrospective updating of data in collaboration with renal centres, in particular for patients who were initially thought to have acute renal failure. As last year, rather than allocating all pre-emptive transplants to the transplanting centre, an attempt was made to allocate these patients to their work up centre. This was not possible for all such patients and consequently some patients probably remained incorrectly allocated to the transplanting centre.

The term established renal failure (ERF) used within this chapter is synonymous with the terms end stage renal failure (ESRF) and end stage renal disease (ESRD), which are in more widespread international usage. Within the UK, patient groups have disliked the term 'end stage' which formerly reflected the inevitable outcome of this disease.

\section{UK Renal Registry coverage}

The UK Renal Registry (UKRR) received individual patient level data from all adult renal centres in the UK ( 5 renal centres in Wales, 6 in Northern Ireland, 9 in Scotland and 52 in England). Data from centres in Scotland were obtained from the Scottish Renal Registry. Data on children and young adults can be found in chapter 5: Demography of the UK Paediatric Renal Replacement Therapy population in 2010.

\section{Geographical variation in incidence rates}

Over the years, there have been wide variations in incidence rates between renal centres. Equity of access to RRT is an important aim but is hard to assess as the need for RRT depends on many variables including medical, social and demographic factors such as underlying conditions, age, gender, social deprivation and ethnicity. Thus, comparison of crude incidence rates by geographical area can be misleading. This year's report again uses age and gender standardisation as well as showing crude rates. It also gives the ethnic minority percentage of each area as this influences incidence rates. More detailed investigations into variation in incidence rates are continuing at the UKRR.

\section{Methods}

Crude incidence rates were calculated per million population (pmp) and age/gender standardised incidence ratios were calculated as detailed in appendix D: Methodology used for Analyses (www.renalreg.com/report-area/report 2011/appendixD.pdf). Briefly, data from all areas covered by the Registry for the relevant year were used to calculate overall age and gender specific incidence rates. The age and gender breakdown of the population in each Primary Care Trust (PCT) area in England, Local Health Board (HB) in Wales, Scottish Health Board (HB) and the Health and Social Care Trust Areas in Northern Ireland (HSC) were obtained from the Office for National Statistics (ONS) [1]. These are referred to by the umbrella term 'PCT/ HB' in this report. The population breakdown was extrapolated by the ONS from the 2001 census data to mid-2010 estimates. For Northern Ireland the population data were aggregated from district council to HSC level. The population breakdown and the overall incidence rates were used to calculate the expected age and gender specific incident numbers for each PCT/HB. The age and gender standardised incidence ratio was the observed incident numbers divided by the expected incident numbers. A ratio below 1 indicated that the observed rate was less than expected given the area's age structure. This was statistically significant if the upper confidence limit was less than 1. Analyses were undertaken for each of the last 6 years and, as the incident numbers for one year can be small especially for smaller areas, a combined 6 years analysis was also done. The proportion of non-Whites in each PCT/HB area was obtained from the ONS from the 2001 Census for Northern Ireland, Scotland and Wales and from the ONS revised estimates for 2007 for England.

\section{Results}

In 2010 the number of adult patients starting RRT in the UK was 6,648 equating to an incidence rate of $107 \mathrm{pmp}$ (table 1.1), slightly lower than in 2009. Wales remained the country with the highest incidence rate (figure 1.1). For England, incidence rates have been stable for the last 5 years. There continued to be very 
Table 1.1. Number of new adult patients starting RRT in the UK in 2010

\begin{tabular}{|c|c|c|c|c|c|}
\hline & England & $\mathrm{N}$ Ireland & Scotland & Wales & UK \\
\hline Number starting RRT & 5,587 & 181 & 494 & 386 & 6,648 \\
\hline${ }^{\mathrm{a}}$ Total estimated population mid-2010 (millions) & 52.2 & 1.8 & 5.2 & 3.0 & 62.3 \\
\hline$(95 \% \mathrm{CI})$ & $(104-110)$ & $(86-115)$ & $(86-103)$ & $(116-141)$ & $(104-109)$ \\
\hline
\end{tabular}

${ }^{a}$ Data extrapolated by the Office for National Statistics-based on the 2001 census

marked gender differences in incidence rates which were $136 \mathrm{pmp}$ (95\% CI 132-140) in males and $79 \mathrm{pmp}$ (95\% CI 75-82) in females. Including incident patients aged under 18 the UK rate was 108 pmp.

Table 1.2 shows incidence rates and standardised incidence ratios for PCT/HBs. The ratios, calculated using combined data from up to six years, have been used to determine areas with significantly high or low incidence rates. Significantly high areas have been shaded with bold text and significantly low areas shaded a lighter grey with italicised text. There were wide variations between areas, with 52 being significantly high and 54 being significantly low out of a total of 177 areas. As would be expected, urban areas with high percentages of non-White residents tended to have high incidence rates. Figure 1.2 shows the positive correlation $(\mathrm{r}=0.81, \mathrm{p}<0.001)$ between the standardised incidence ratio and the percentage of the $\mathrm{PCT} / \mathrm{HB}$ that is nonWhite.

Confidence intervals are not presented for the crude rates per million population but figures D1 and D2 in

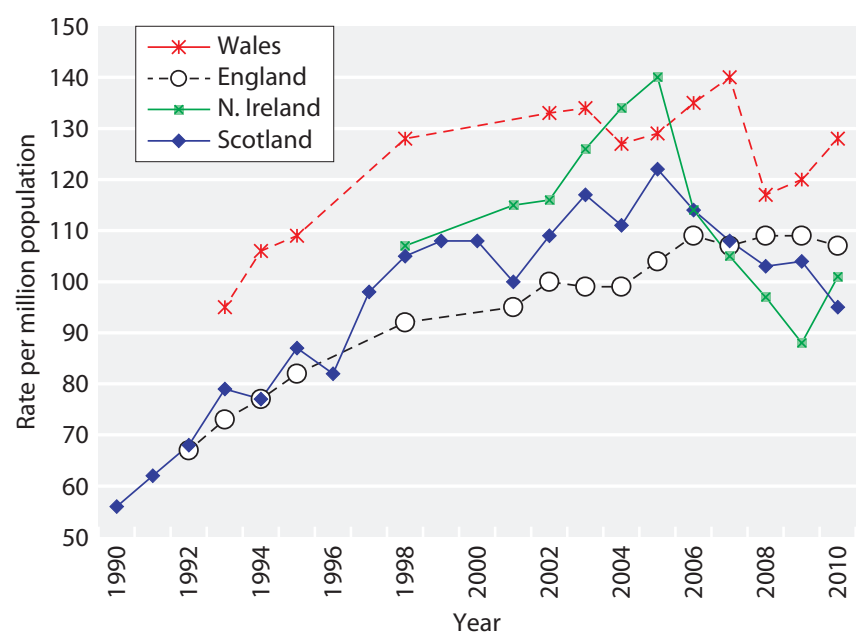

Fig. 1.1. RRT incidence rates in the countries of the UK 19902010 appendix D can be used to determine if a PCT/HB falls within the 95\% confidence interval around the national average rate.

The number of new patients starting RRT at each renal centre from 2005 to 2010 is shown in table 1.3 along with the percentage change in these numbers between these years for those centres with full reporting during that period. Some centres have had an increase in new patients over time and others have fallen. The variation may reflect chance fluctuation, the introduction of new centres, changes in catchment populations or in completeness of reporting. Variation may also be due to changing incidence of established renal failure (increases in underlying disease prevalence, survival from co-morbid conditions and recognition of ERF), changes to treatment thresholds or the introduction of conservative care programmes. Incidence rates per million population by centre were presented for the first time in last year's report after a detailed piece of work was done to estimate the centre's catchment populations. These rates are again reported this year. For a full description of the methodology used to estimate the catchment populations see appendix E: Methodology for Estimating Catchment Populations Analyses (www.renalreg.com/report-area/report 2011/ appendix-E.pdf). In brief, the patient postcode for each prevalent dialysis patient in 2007 was used to create a series of overlapping areas corresponding to each renal centre. These small areas were then assigned to a Census Area Statistics ward using geographical information system technology and the population in each area assigned to its respective renal centre. These estimates will not be accurate for new centres and centres with changes in catchment populations since 2007 (e.g. Bristol, Cambridge and Ipswich, which have lost catchment population since 2007 and Dorset which gained catchment population); in addition the analysis used dialysis patients only and transplant patients may come from a different catchment population. Estimation of centre's catchment populations 
Table 1.2. Crude adult incidence rates (pmp) and age/gender standardised incidence ratios 2005-2010

$\mathrm{PCT} / \mathrm{HB}=\mathrm{PCT}$ in England, Health and Social Care Trust Areas in Northern Ireland, Local Health Boards in Wales and Health Boards in Scotland $\mathrm{O} / \mathrm{E}=$ standardised incidence ratio

$\mathrm{LCL}=$ lower $95 \%$ confidence limit

$\mathrm{UCL}=$ upper $95 \%$ confidence limit

$\mathrm{pmp}=$ per million population

$\mathrm{pmp}^{\mathrm{a}}=$ per million population per year

Blank cells $=$ no data returned to the UKRR for that year

Areas with significantly low incidence ratios over six years are italicised in greyed areas, those with significantly high incidence ratios over six years are bold in greyed areas

$\%$ non-White = percentage of the PCT/HB population that is non-White, from 2001 census (revised by ONS to 2007 for England)

For those areas not covered by the Registry for the entire period 2005-2010, the combined years standardised incidence ratios and incidence rates are averages for the years covered by the Registry

\begin{tabular}{|c|c|c|c|c|c|c|c|c|c|c|c|c|c|c|}
\hline \multirow[b]{2}{*}{ UK Area } & \multirow[b]{2}{*}{ PCT/HB } & \multirow{2}{*}{$\begin{array}{c}\text { Tot pop } \\
(2010) \\
\end{array}$} & \multirow{2}{*}{$\begin{array}{c}2005 \\
\mathrm{O} / \mathrm{E}\end{array}$} & \multirow{2}{*}{$\begin{array}{c}2006 \\
\mathrm{O} / \mathrm{E}\end{array}$} & \multirow{2}{*}{$\begin{array}{c}2007 \\
\mathrm{O} / \mathrm{E}\end{array}$} & \multirow{2}{*}{$\begin{array}{r}2008 \\
\mathrm{O} / \mathrm{E}\end{array}$} & \multirow{2}{*}{$\begin{array}{r}2009 \\
\mathrm{O} / \mathrm{E}\end{array}$} & \multicolumn{2}{|c|}{2010} & \multicolumn{4}{|c|}{ 2005-2010 } & \multirow{2}{*}{$\begin{array}{l}\% \text { non- } \\
\text { White }\end{array}$} \\
\hline & & & & & & & & $\mathrm{O} / \mathrm{E}$ & pmp & $\mathrm{O} / \mathrm{E}$ & LCL & UCL & $\mathrm{pmp}^{\mathrm{a}}$ & \\
\hline North & County Durham & 510,800 & 0.89 & 0.86 & 0.67 & 0.67 & 0.76 & 0.78 & 88 & 0.77 & 0.68 & 0.87 & 88 & 2.5 \\
\hline \multirow[t]{11}{*}{ East } & Darlington & 100,600 & 0.55 & 0.61 & 1.15 & 0.97 & 0.96 & 0.99 & 109 & 0.87 & 0.68 & 1.13 & 98 & 3.3 \\
\hline & Gateshead & 192,000 & 0.80 & 0.90 & 0.78 & 0.55 & 0.90 & 0.79 & 89 & 0.79 & 0.65 & 0.95 & 89 & 3.8 \\
\hline & Hartlepool & 91,400 & 0.83 & 1.37 & 0.50 & 1.29 & 0.78 & 0.61 & 66 & 0.90 & 0.69 & 1.17 & 98 & 2.6 \\
\hline & Middlesbrough & 142,100 & 1.02 & 1.38 & 1.18 & 1.18 & 0.62 & 1.49 & 148 & 1.14 & 0.94 & 1.40 & 115 & 8.6 \\
\hline & Newcastle & 292,200 & 1.08 & 0.82 & 1.18 & 1.00 & 0.89 & 0.73 & 68 & 0.95 & 0.81 & 1.11 & 90 & 9.7 \\
\hline & North Tyneside & 198,400 & 0.88 & 0.79 & 0.75 & 0.49 & 0.88 & 0.95 & 106 & 0.79 & 0.65 & 0.95 & 89 & 3.6 \\
\hline & Northumberland & 312,100 & 0.64 & 0.71 & 0.74 & 0.67 & 0.61 & 0.60 & 74 & 0.66 & 0.57 & 0.78 & 82 & 2.2 \\
\hline & Redcar and Cleveland & 137,300 & 0.96 & 0.91 & 0.98 & 0.74 & 0.85 & 0.69 & 80 & 0.85 & 0.69 & 1.06 & 101 & 3.0 \\
\hline & South Tyneside & 154,100 & 0.95 & 1.07 & 1.14 & 0.57 & 1.24 & 0.76 & 84 & 0.96 & 0.79 & 1.17 & 108 & 4.8 \\
\hline & Stockton-on-Tees Teaching & 192,600 & 0.81 & 0.87 & 0.63 & 0.83 & 0.68 & 0.89 & 93 & 0.78 & 0.64 & 0.96 & 83 & 4.7 \\
\hline & Sunderland Teaching & 283,400 & 0.80 & 0.73 & 1.05 & 0.86 & 0.92 & 1.04 & 113 & 0.90 & 0.77 & 1.05 & 99 & 3.3 \\
\hline North & Ashton, Leigh and Wigan & 307,200 & 0.89 & 0.67 & 0.86 & 0.86 & 0.59 & 0.69 & 75 & 0.76 & 0.65 & 0.89 & 83 & 2.9 \\
\hline \multirow[t]{23}{*}{ West } & $\begin{array}{l}\text { Blackburn with Darwen } \\
\text { Teaching }\end{array}$ & 140,000 & 1.43 & 1.28 & 1.30 & 0.46 & 0.91 & 1.09 & 100 & 1.08 & 0.87 & 1.33 & 100 & 22.7 \\
\hline & Blackpool & 140,200 & 0.82 & 0.54 & 0.91 & 0.91 & 0.96 & 0.62 & 71 & 0.79 & 0.64 & 0.99 & 93 & 3.7 \\
\hline & Bolton Teaching & 266,500 & 0.71 & 0.88 & 0.89 & 0.96 & 0.88 & 1.42 & 146 & 0.96 & 0.82 & 1.12 & 100 & 12.3 \\
\hline & Bury & 183,500 & 0.74 & 0.55 & 0.71 & 0.77 & 0.71 & 0.73 & 76 & 0.70 & 0.57 & 0.87 & 74 & 8.5 \\
\hline & Central and Eastern Cheshire & 457,200 & & & 0.61 & 0.65 & 0.72 & 0.76 & 87 & 0.68 & 0.58 & 0.80 & 80 & 3.4 \\
\hline & Central Lancashire & 459,200 & 0.74 & 0.58 & 0.81 & 0.87 & 0.92 & 0.64 & 70 & 0.76 & 0.67 & 0.87 & 83 & 6.7 \\
\hline & Cumbria Teaching & 494,400 & 0.84 & 0.61 & 0.62 & 0.71 & 0.58 & 0.67 & 83 & 0.67 & 0.59 & 0.76 & 83 & 2.0 \\
\hline & East Lancashire Teaching & 381,200 & 0.68 & 0.90 & 0.72 & 0.65 & 0.81 & 0.69 & 73 & 0.74 & 0.64 & 0.86 & 80 & 9.4 \\
\hline & Halton and St Helens & 296,700 & 1.21 & 1.21 & 1.01 & 0.55 & 0.88 & 0.91 & 98 & 0.96 & 0.83 & 1.11 & 105 & 2.1 \\
\hline & $\begin{array}{l}\text { Heywood, Middleton and } \\
\text { Rochdale }\end{array}$ & 205,000 & & & 0.90 & 1.00 & 1.13 & 0.82 & 83 & 0.96 & 0.78 & 1.20 & 99 & 12.6 \\
\hline & Knowsley & 149,200 & 0.67 & 0.89 & 1.03 & 0.51 & 0.76 & 0.91 & 94 & 0.80 & 0.63 & 1.00 & 83 & 2.8 \\
\hline & Liverpool & 445,300 & 1.34 & 1.21 & 1.11 & 1.15 & 1.21 & 0.90 & 88 & 1.15 & 1.03 & 1.29 & 114 & 8.3 \\
\hline & Manchester Teaching & 498,800 & & & 1.25 & 1.32 & 1.38 & 1.29 & 100 & 1.31 & 1.14 & 1.50 & 104 & 23.4 \\
\hline & North Lancashire Teaching & 329,100 & 0.38 & 0.51 & 0.59 & 0.52 & 0.70 & 0.62 & 76 & 0.56 & 0.47 & 0.66 & 68 & 4.2 \\
\hline & Oldham & 219,600 & 0.51 & 0.84 & 0.90 & 1.08 & 0.85 & 0.92 & 91 & 0.85 & 0.71 & 1.02 & 86 & 12.2 \\
\hline & Salford & 229,100 & 0.36 & 0.96 & 0.53 & 1.05 & 0.96 & 1.39 & 135 & 0.88 & 0.73 & 1.05 & 87 & 7.7 \\
\hline & Sefton & 272,800 & 0.91 & 0.83 & 0.57 & 0.90 & 0.77 & 0.98 & 117 & 0.83 & 0.71 & 0.96 & 100 & 2.6 \\
\hline & Stockport & 284,700 & & & 0.80 & 0.77 & 0.61 & 0.88 & 98 & 0.77 & 0.63 & 0.93 & 87 & 6.4 \\
\hline & Tameside and Glossop & 250,700 & & & 1.36 & 0.71 & 0.93 & 0.96 & 100 & 0.99 & 0.82 & 1.20 & 105 & 5.9 \\
\hline & Trafford & 217,100 & & & 1.12 & 0.60 & 1.06 & 1.36 & 143 & 1.03 & 0.85 & 1.26 & 111 & 11.2 \\
\hline & Warrington & 199,100 & 0.82 & 0.73 & 0.74 & 0.60 & 1.00 & 0.56 & 60 & 0.74 & 0.61 & 0.91 & 80 & 3.5 \\
\hline & Western Cheshire & 234,300 & 0.56 & 0.88 & 0.90 & 0.54 & 0.88 & 1.16 & 137 & 0.82 & 0.70 & 0.97 & 97 & 3.1 \\
\hline & Wirral & 308,800 & 1.25 & 0.80 & 0.75 & 0.75 & 0.83 & 0.74 & 84 & 0.85 & 0.73 & 0.98 & 98 & 2.8 \\
\hline
\end{tabular}


Table 1.2. Continued

\begin{tabular}{|c|c|c|c|c|c|c|c|c|c|c|c|c|c|c|}
\hline \multirow[b]{2}{*}{ UK Area } & \multirow[b]{2}{*}{ PCT/HB } & \multirow{2}{*}{$\begin{array}{c}\text { Tot pop } \\
(2010)\end{array}$} & \multirow{2}{*}{$\begin{array}{c}2005 \\
\mathrm{O} / \mathrm{E}\end{array}$} & \multirow{2}{*}{$\begin{array}{c}2006 \\
O / E\end{array}$} & \multirow{2}{*}{$\begin{array}{c}2007 \\
\mathrm{O} / \mathrm{E}\end{array}$} & \multirow{2}{*}{$\begin{array}{c}2008 \\
\mathrm{O} / \mathrm{E}\end{array}$} & \multirow{2}{*}{$\begin{array}{l}2009 \\
\mathrm{O} / \mathrm{E}\end{array}$} & \multicolumn{2}{|c|}{2010} & \multicolumn{4}{|c|}{$2005-2010$} & \multirow{2}{*}{$\begin{array}{l}\% \text { non- } \\
\text { White }\end{array}$} \\
\hline & & & & & & & & $\mathrm{O} / \mathrm{E}$ & pmp & $\mathrm{O} / \mathrm{E}$ & LCL & UCL & $\mathbf{p m p}^{\mathrm{a}}$ & \\
\hline \multirow{10}{*}{$\begin{array}{l}\text { Yorkshire } \\
\text { and the } \\
\text { Humber }\end{array}$} & Barnsley & 227,500 & 0.74 & 1.01 & 0.87 & 1.11 & 0.94 & 1.25 & 136 & 0.99 & 0.84 & 1.16 & 109 & 2.7 \\
\hline & Calderdale & 202,800 & 1.01 & 0.91 & 0.92 & 0.83 & 1.05 & 0.52 & 54 & 0.87 & 0.73 & 1.05 & 93 & 9.8 \\
\hline & Doncaster & 290,900 & 0.67 & 0.79 & 0.64 & 0.80 & 1.06 & 0.93 & 103 & 0.82 & 0.70 & 0.95 & 91 & 4.3 \\
\hline & East Riding of Yorkshire & 338,500 & 1.07 & 0.67 & 0.63 & 0.96 & 0.90 & 0.69 & 86 & 0.82 & 0.71 & 0.94 & 103 & 3.0 \\
\hline & Kirklees & 409,900 & 0.77 & 1.18 & 0.72 & 0.79 & 1.09 & 0.93 & 93 & 0.92 & 0.80 & 1.04 & 93 & 16.0 \\
\hline & Leeds & 798,700 & 1.14 & 0.92 & 0.82 & 0.97 & 0.81 & 0.67 & 64 & 0.89 & 0.81 & 0.98 & 85 & 11.8 \\
\hline & North East Lincolnshire & 158,800 & 1.17 & 1.11 & 1.07 & 1.12 & 0.83 & 0.68 & 76 & 1.00 & 0.82 & 1.20 & 111 & 3.1 \\
\hline & North Lincolnshire & 157,500 & 1.07 & 1.01 & 0.65 & 0.81 & 0.75 & 0.71 & 83 & 0.83 & 0.68 & 1.02 & 97 & 3.2 \\
\hline & North Yorkshire and York & 802,100 & 0.91 & 0.87 & 0.81 & 0.73 & 0.81 & 0.63 & 74 & 0.79 & 0.72 & 0.87 & 94 & 3.7 \\
\hline & Rotherham & 254,300 & 1.14 & 0.91 & 1.03 & 1.31 & 0.95 & 1.16 & 126 & 1.08 & 0.93 & 1.25 & 119 & 5.2 \\
\hline \multirow{8}{*}{$\begin{array}{l}\text { East } \\
\text { Midlands }\end{array}$} & Derby City & 247,100 & 1.19 & 1.21 & 1.03 & 1.62 & 1.37 & 1.05 & 105 & 1.25 & 1.08 & 1.44 & 127 & 15.0 \\
\hline & Derbyshire County & 729,900 & 0.69 & 0.66 & 0.82 & 1.03 & 0.77 & 0.74 & 86 & 0.79 & 0.71 & 0.87 & 92 & 3.2 \\
\hline & Leicester City & 306,800 & 1.55 & 1.47 & 1.75 & 1.63 & 1.40 & 1.82 & 156 & 1.60 & 1.42 & 1.81 & 140 & 38.2 \\
\hline & $\begin{array}{l}\text { Leicestershire County and } \\
\text { Rutland }\end{array}$ & 687,200 & 0.75 & 0.86 & 0.85 & 0.72 & 0.78 & 0.96 & 108 & 0.82 & 0.74 & 0.91 & 94 & 7.7 \\
\hline & Lincolnshire Teaching & 705,000 & 1.03 & 0.76 & 0.79 & 0.71 & 0.73 & 0.89 & 109 & 0.82 & 0.74 & 0.90 & 101 & 3.3 \\
\hline & Northamptonshire Teaching & 687,600 & 0.81 & 0.88 & 0.97 & 1.20 & 0.83 & 0.82 & 86 & 0.92 & 0.83 & 1.01 & 97 & 7.4 \\
\hline & Nottingham City & 306,300 & 1.40 & 1.38 & 0.96 & 1.31 & 1.42 & 1.50 & 124 & 1.33 & 1.16 & 1.52 & 112 & 18.7 \\
\hline & $\begin{array}{l}\text { Nottinghamshire County } \\
\text { Teaching }\end{array}$ & 668,000 & 1.19 & 1.16 & 1.04 & 0.89 & 1.03 & 0.91 & 103 & 1.04 & 0.95 & 1.13 & 119 & 5.1 \\
\hline \multirow{10}{*}{$\begin{array}{l}\text { West } \\
\text { Midlands }\end{array}$} & Shropshire County & 293,400 & 0.90 & 0.96 & 0.79 & 1.11 & 0.72 & 0.91 & 112 & 0.90 & 0.78 & 1.03 & 112 & 3.0 \\
\hline & Solihull & 206,300 & 1.22 & 1.32 & 0.80 & 0.97 & 1.32 & 0.98 & 111 & 1.10 & 0.94 & 1.29 & 127 & 9.0 \\
\hline & South Birmingham & 342,200 & 1.28 & 1.09 & 1.29 & 1.64 & 1.39 & 1.10 & 105 & 1.30 & 1.15 & 1.47 & 126 & 17.9 \\
\hline & South Staffordshire & 611,300 & & & 0.95 & 0.90 & 0.80 & 1.03 & 118 & 0.92 & 0.81 & 1.04 & 107 & 4.7 \\
\hline & Stoke on Trent & 248,000 & & & 1.27 & 1.01 & 1.34 & 1.26 & 133 & 1.22 & 1.03 & 1.45 & 131 & 7.1 \\
\hline & Telford and Wrekin & 162,400 & 0.74 & 1.34 & 1.59 & 1.00 & 1.17 & 1.45 & 148 & 1.22 & 1.02 & 1.45 & 126 & 6.6 \\
\hline & Walsall Teaching & 256,800 & 1.18 & 1.44 & 1.21 & 1.35 & 1.02 & 1.88 & 202 & 1.35 & 1.18 & 1.54 & 147 & 14.7 \\
\hline & Warwickshire & 536,200 & 0.95 & 1.05 & 1.03 & 0.97 & 0.99 & 1.20 & 136 & 1.03 & 0.93 & 1.14 & 119 & 6.7 \\
\hline & Wolverhampton City & 239,300 & 1.67 & 1.27 & 1.02 & 1.45 & 1.12 & 1.51 & 159 & 1.34 & 1.16 & 1.53 & 142 & 23.8 \\
\hline & Worcestershire & 557,300 & 0.80 & 0.62 & 0.83 & 0.95 & 1.07 & 0.79 & 93 & 0.84 & 0.76 & 0.94 & 100 & 4.4 \\
\hline \multirow{7}{*}{$\begin{array}{l}\text { East of } \\
\text { England }\end{array}$} & Bedfordshire & 416,300 & 0.66 & 1.02 & 0.56 & 0.74 & 0.82 & 0.89 & 94 & 0.78 & 0.68 & 0.90 & 83 & 9.3 \\
\hline & Cambridgeshire & 616,400 & 0.94 & 1.09 & 0.83 & 0.81 & 1.00 & 0.80 & 84 & 0.91 & 0.82 & 1.01 & 98 & 7.4 \\
\hline & Hertfordshire & $1,107,500$ & 0.74 & 0.93 & 0.77 & 0.94 & 0.83 & 0.89 & 92 & 0.85 & 0.79 & 0.92 & 89 & 9.9 \\
\hline & Great Yarmouth and Waveney & 214,700 & 1.29 & 1.29 & 1.13 & 1.21 & 0.86 & 1.11 & 140 & 1.15 & 0.99 & 1.32 & 146 & 3.5 \\
\hline & Luton & 198,900 & 1.32 & 1.15 & 1.49 & 1.05 & 0.99 & 1.07 & 96 & 1.17 & 0.99 & 1.40 & 106 & 31.5 \\
\hline & Mid Essex & 374,500 & 0.85 & 0.95 & 0.93 & 0.81 & 0.88 & 0.78 & 85 & 0.87 & 0.76 & 0.99 & 96 & 5.1 \\
\hline & Norfolk & 764,800 & 1.16 & 1.01 & 1.06 & 0.90 & 0.71 & 0.82 & 102 & 0.94 & 0.86 & 1.02 & 117 & 3.9 \\
\hline
\end{tabular}


Table 1.2. Continued

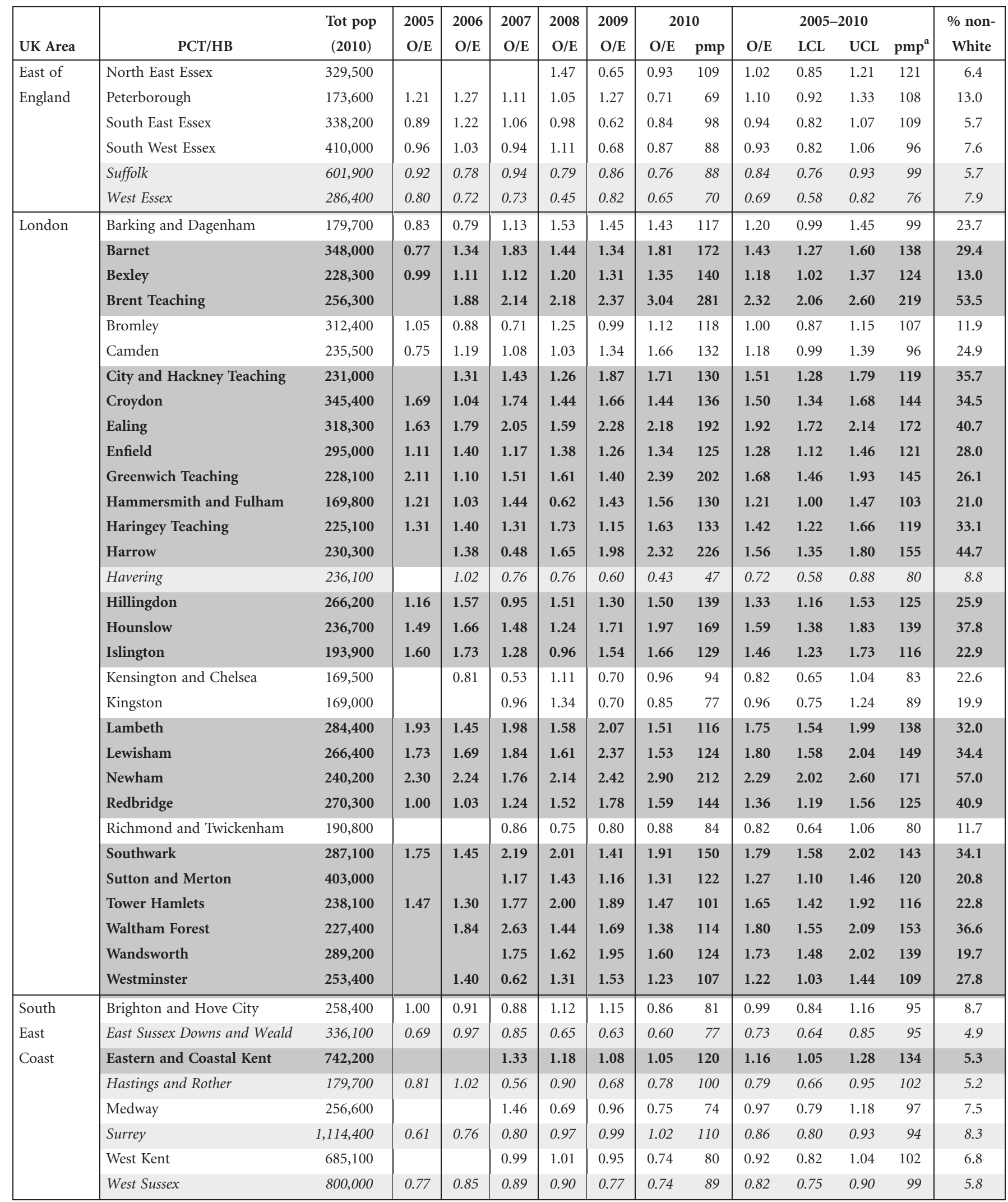

c6 
Table 1.2. Continued






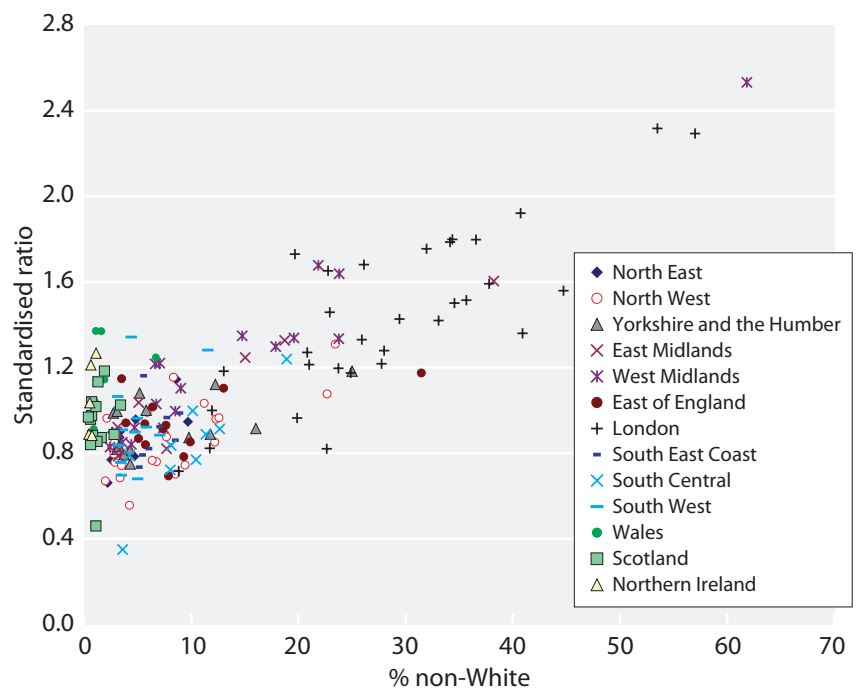

Fig. 1.2. Age/gender standardised incidence ratio (2005-2010) by percentage non-White therefore remains an inexact science and these figures should be regarded as indicative only. This methodology was used for England only. Estimates of the catchment populations in Wales and Northern Ireland were supplied by personal communication from Dr K Donovan, Dr A Williams and Dr D Fogarty. No data were available from Scotland.

There was a fall of over $20 \%$ in the number of new patients for Scotland and Northern Ireland from 2005 to 2010. There was a small fall for Wales over the same period. After omitting the four English centres which did not contribute data for 2005 there was an increase of almost 5\% in new patients for England from 2005 to 2010. However, this change occurred from 2005 to 2006 after which the number of patients was relatively stable. Across all four countries the change averages out at an increase of $0.5 \%$.

Table 1.3. Number of new patients accepted by individual renal centres reporting to the UK Renal Registry $2005-2010$

\begin{tabular}{|c|c|c|c|c|c|c|c|c|c|c|}
\hline \multirow[b]{2}{*}{ Country } & \multirow[b]{2}{*}{ Centre } & \multicolumn{6}{|c|}{ Year } & \multirow{2}{*}{$\begin{array}{l}\text { Catchment } \\
\text { population } \\
\text { (millions) }\end{array}$} & \multirow{2}{*}{$\begin{array}{l}2010 \\
\text { rate } \\
\text { pmp }\end{array}$} & \multirow[b]{2}{*}{$(95 \% \mathrm{CI})$} \\
\hline & & 2005 & 2006 & 2007 & 2008 & 2009 & 2010 & & & \\
\hline \multirow[t]{32}{*}{ England } & B Heart & 119 & 116 & 101 & 105 & 99 & 95 & 0.72 & 131 & $(105-157)$ \\
\hline & $\mathrm{B} \mathrm{QEH}$ & 199 & 186 & 225 & 268 & 255 & 197 & 1.62 & 121 & $(104-138)$ \\
\hline & Basldn & 32 & 45 & 39 & 40 & 26 & 32 & 0.41 & 78 & $(51-106)$ \\
\hline & Bradfd & 67 & 50 & 88 & 63 & 61 & 64 & 0.58 & 111 & $(83-138)$ \\
\hline & Brightn & 112 & 131 & 120 & 121 & 120 & 107 & 1.20 & 90 & $(73-106)$ \\
\hline & Bristol & 175 & 176 & 156 & 176 & 158 & 169 & 1.57 & 108 & $(91-124)$ \\
\hline & $\mathrm{Camb}^{\mathrm{a}}$ & 111 & 156 & 128 & 109 & 136 & 108 & $1.27^{\mathrm{a}}$ & $85^{\mathrm{a}}$ & $(69-101)$ \\
\hline & Carlis & 31 & 27 & 26 & 30 & 24 & 21 & 0.31 & 67 & $(38-95)$ \\
\hline & Carsh & 183 & 186 & 194 & 216 & 208 & 221 & 1.92 & 115 & $(100-131)$ \\
\hline & Chelms $^{\mathrm{a}}$ & 40 & 50 & 52 & 36 & 52 & 42 & $0.47^{\mathrm{a}}$ & $90^{\mathrm{a}}$ & $(63-117)$ \\
\hline & Colchr ${ }^{\mathrm{b}}$ & $\mathrm{n} / \mathrm{a}$ & $\mathrm{n} / \mathrm{a}$ & $\mathrm{n} / \mathrm{a}$ & 58 & 17 & 32 & b & b & $\mathrm{b}$ \\
\hline & Covnt & 84 & 104 & 113 & 116 & 118 & 118 & 0.87 & 136 & $(111-160)$ \\
\hline & Derby & 71 & 70 & 63 & 96 & 78 & 80 & 0.65 & 124 & $(97-151)$ \\
\hline & Donc $^{b}$ & $\mathrm{n} / \mathrm{a}$ & $\mathrm{n} / \mathrm{a}$ & 20 & 26 & 40 & 44 & $\mathrm{~b}$ & $\mathrm{~b}$ & $\mathrm{~b}$ \\
\hline & Dorset & 49 & 53 & 65 & 85 & 76 & 72 & 0.73 & 99 & $(76-122)$ \\
\hline & Dudley & 38 & 45 & 40 & 46 & 69 & 41 & 0.42 & 99 & $(69-129)$ \\
\hline & Exeter & 111 & 105 & 126 & 135 & 145 & 136 & 1.03 & 132 & $(110-155)$ \\
\hline & Glouc & 61 & 74 & 58 & 47 & 79 & 58 & 0.58 & 101 & $(75-127)$ \\
\hline & Hull & 125 & 105 & 99 & 113 & 101 & 88 & 0.99 & 89 & $(71-108)$ \\
\hline & Ipswi $^{\mathrm{a}}$ & 59 & 42 & 40 & 38 & 38 & 34 & $0.56^{\mathrm{a}}$ & $61^{\mathrm{a}}$ & $(40-81)$ \\
\hline & $\stackrel{1}{\text { Kent }}$ & & & 172 & 140 & 131 & 134 & 1.16 & 115 & $(96-135)$ \\
\hline & L Barts & 187 & 190 & 214 & 206 & 239 & 207 & 1.68 & 123 & $(106-140)$ \\
\hline & L Guys & 148 & 152 & 168 & 164 & 176 & 144 & 1.15 & 125 & $(104-145)$ \\
\hline & L Kings & 131 & 110 & 121 & 151 & 128 & 148 & 0.97 & 153 & $(128-177)$ \\
\hline & L Rfree & 132 & 194 & 185 & 173 & 170 & 203 & 1.50 & 135 & $(116-154)$ \\
\hline & L St.G & & & 93 & 100 & 109 & 83 & 0.59 & 142 & $(111-172)$ \\
\hline & L West & 302 & 313 & 278 & 318 & 357 & 367 & 2.23 & 165 & $(148-182)$ \\
\hline & Leeds & 172 & 178 & 127 & 159 & 154 & 130 & 1.65 & 79 & $(65-93)$ \\
\hline & Leic & 226 & 241 & 244 & 243 & 228 & 250 & 2.32 & 108 & $(94-121)$ \\
\hline & Liv Ain & 29 & 35 & 36 & 42 & 38 & 49 & 0.29 & 169 & $(122-216)$ \\
\hline & Liv RI & 139 & 141 & 112 & 102 & 110 & 102 & 1.20 & 85 & $(69-102)$ \\
\hline & M Hope & 110 & 132 & 121 & 142 & 125 & 146 & 1.42 & 103 & $(86-119)$ \\
\hline
\end{tabular}


Table 1.3. Continued



Blank cells $=$ no data returned to the registry for that year $\mathrm{n} / \mathrm{a}$ - renal centre not yet operational

${ }^{a}$ Some reduction required to the population and increase to the rate after the opening of Colchester renal centre and the expansion of Doncaster renal centre

${ }^{\mathrm{b}}$ Colchester renal centre was opened in 2007, Doncaster was still expanding and so catchment populations could not be calculated

${ }^{\mathrm{c}}$ Percentage change not given as not all centres contributing for 2005 


\section{Demographics and clinical characteristics of patients starting RRT}

\section{Methods}

Age, gender, primary renal disease, ethnic origin and treatment modality were examined for patients starting RRT.

Some centres electronically upload ethnicity coding to their renal information technology (IT) system from the hospital Patient Administration Systems (PAS). Ethnicity coding in these PAS systems is based on self-reported ethnicity and uses a different coding system [2]. For the remaining centres, ethnicity coding is performed by clinical staff and recorded directly into the renal IT system (using a variety of coding systems). For all these analyses, data on ethnic origin were grouped into Whites, South Asians, Blacks, Chinese and Others. The details of regrouping of the PAS codes into the above ethnic categories are provided in appendix H: Ethnicity and ERA-EDTA Coding (www.renalreg. com/report-area/report 2011/appendix-H.pdf). Chi-squared, Fisher's exact, ANOVA and Kruskal Wallis tests were used as appropriate to test for significant differences.

Estimated glomerular filtration rate (eGFR) at the start of RRT was studied amongst patients with eGFR data within 14 days before the start of RRT. The eGFR was calculated using the abbreviated 4 variable MDRD study equation [3]. For the purpose of the eGFR calculation, patients who had missing ethnicity but a valid serum creatinine measurement were classed as Whites. The eGFR values were log transformed in order to normalise the data. Patients with an eGFR $>20 \mathrm{ml} / \mathrm{min} / 1.73 \mathrm{~m}^{2}$ were excluded from the eGFR analyses due to concerns about possible data extraction errors.

\section{Results}

Age

Incidence rates within the UK have levelled off overall in the last four years and declined slightly in the under 65 age groups (figure 1.3).

Figure 1.4 shows RRT incidence rates for 2010 by age group. For men, the peak was in the 80-84 age group, for women 75-79 and overall 75-79 (the higher male peak at 80-84 does not shift the overall figure as there are relatively few people in this age group).

In 2010, the median age of patients starting renal replacement therapy was 64.9 years (table 1.4) and this had changed little over the previous six years (data not shown). The median age of non-White patients was considerably lower at 57.1 years. This reflects the younger age distribution of ethnic minority populations in general compared with the White population $(5.1 \%$ of ethnic minorities were over 65 years old compared to $16.9 \%$ of Whites) [4] and the higher rates of diabetes in South Asian and Black populations. The median age of patients starting RRT in England was lower than that for N Ireland, Scotland and Wales possibly reflecting the larger percentage of the population being non-White in England.



Fig. 1.3. UK incident RRT rates between 1980 and 2010

Figure 1.5 shows that the $45-54,55-64$ and $65-74$ age groups contained the most patients starting on peritoneal dialysis whereas the 65-74 age group contained the most patients starting on haemodialysis closely followed by the 75-84 age group.

There were large differences between centres in the median age of incident patients (figure 1.6). This reflects differences in the age and ethnic structure of the catchment populations and also chance fluctuations, particularly in small centres. The median age of patients treated at transplant centres was 63.1 years (IQR 49.7, 74.2) and at non-transplanting centres 66.5 years (IQR 52.9, 76.0) $(\mathrm{p}<0.0001)$.

Whilst the median age of patients has risen only slightly over the last 10 years the percentage of patients aged over 75 years has risen from $22.3 \%$ to $25.6 \%$.

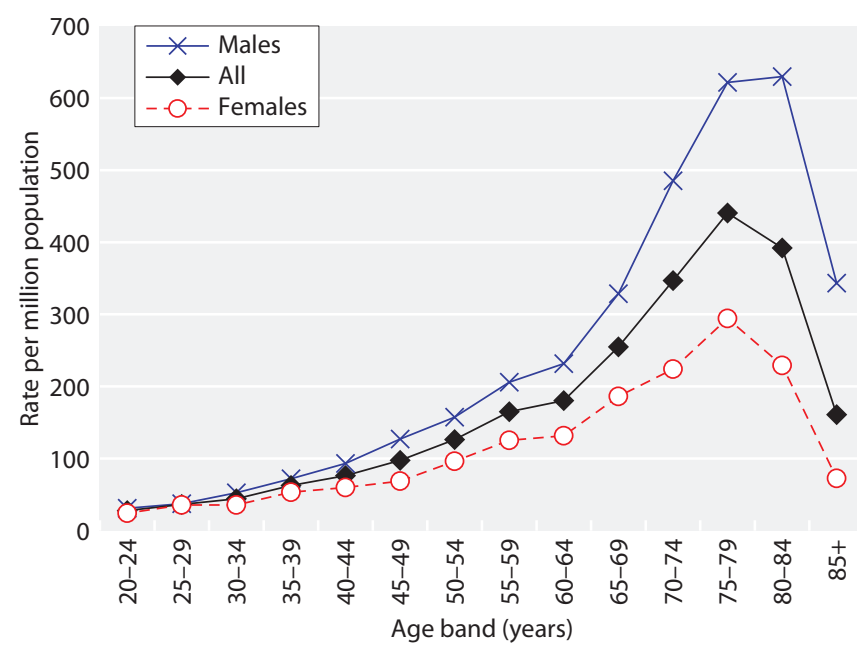

Fig. 1.4. Incidence rates by age and gender in 2010 
Table 1.4. Median and inter-quartile range of the age of patients starting renal replacement therapy in 2010 by country

\begin{tabular}{lcc}
\hline Country & Median & IQR \\
\hline England & 64.4 & $(50.6-75.1)$ \\
N Ireland & 67.6 & $(57.1-77.8)$ \\
Scotland & 65.3 & $(51.9-75.0)$ \\
Wales & 68.5 & $(56.4-77.2)$ \\
UK & $\mathbf{6 4 . 9}$ & $(\mathbf{5 1 . 0 - 7 5 . 2 )}$ \\
\hline
\end{tabular}

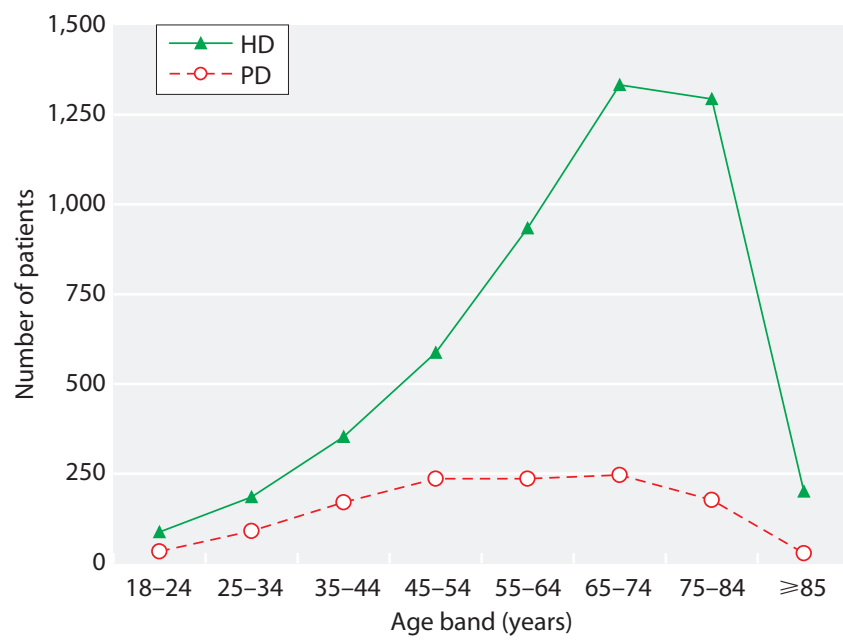

Fig. 1.5. Number of incident patients in 2010, by age group and initial dialysis modality

There is 6-fold variation in crude incidence rates in the over 75 year age group between PCT/HBs (excluding outlying areas) using a combined 6 year cohort. The absolute range in rates was from 0 per million age related population (pmarp) (Shetland) to 1,003 pmarp (Heart of Birmingham). Incidence rates in older patients were able
80

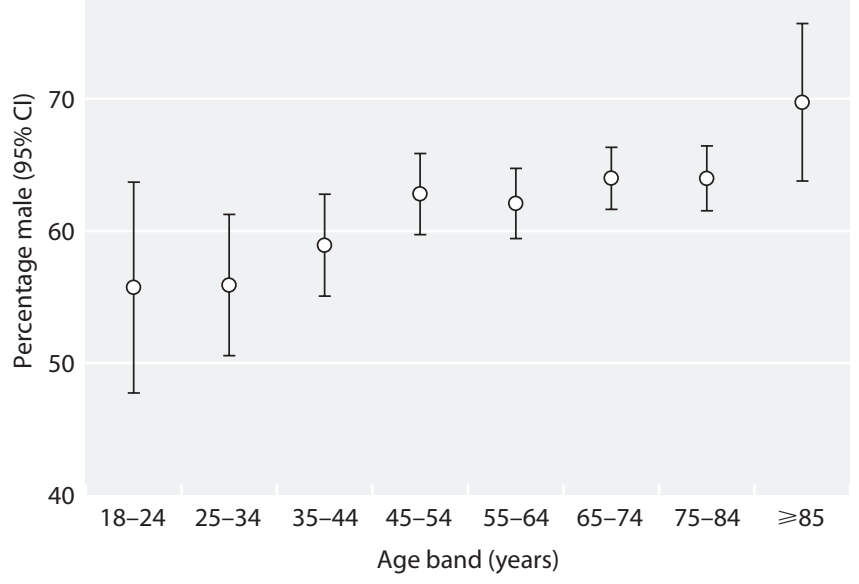

Fig. 1.7. Percentage of patients starting RRT in 2010 who were male, by age group

to explain $55 \%$ of the variation in overall RRT incidence rate suggesting that this is one of the explanatory factors for the variation in RRT incidence seen in the UK. The wide range of treatment rates suggests there is geographical variation in the prevalence of co-morbid and predisposing renal conditions within the UK as well as uncertainty within the renal community about the suitability of older patients for dialysis. The median age of new patients with diabetes was slightly younger than the overall median at 63.9 years and this has not changed over the last 5 years.

\section{Gender}

As in previous years, more men than women started RRT $(62.6 \%$ male). The percentage male was above 50 for all age groups and increased with increasing age group (figure 1.7).

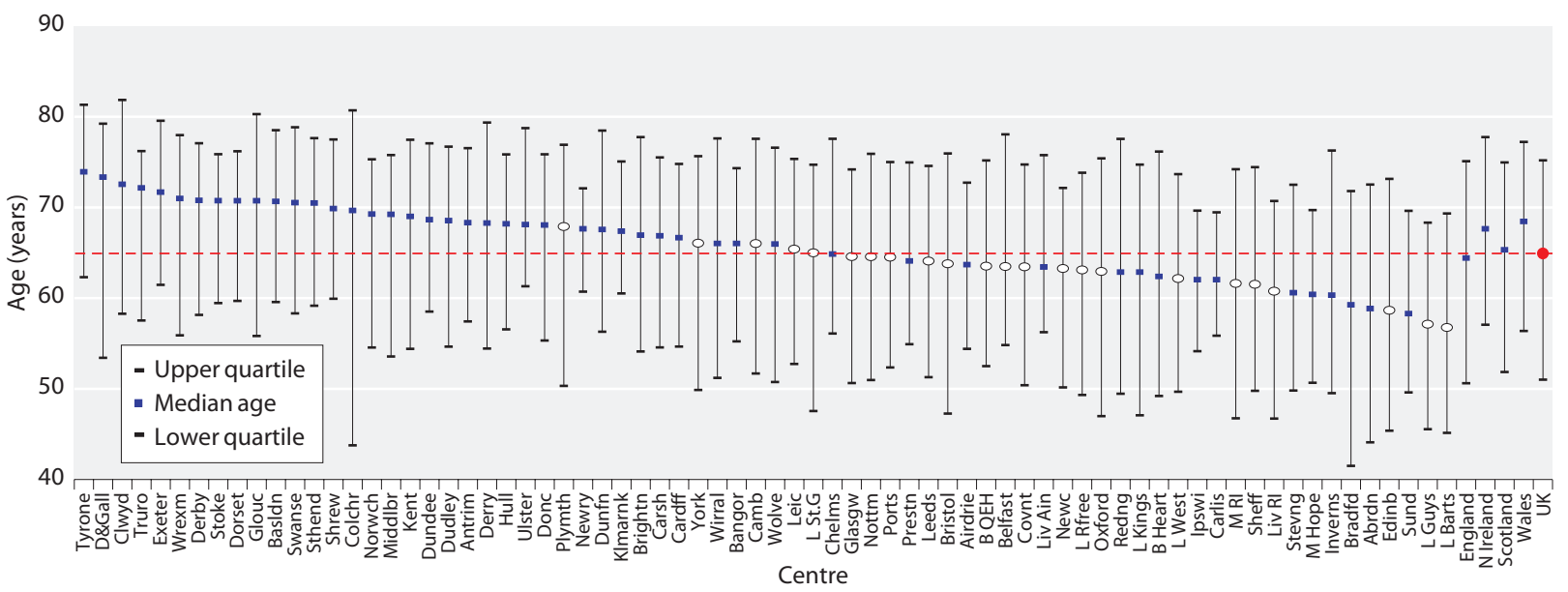

Fig. 1.6. Median age of incident patients in each centre in 2010 White points indicate transplant centres 
Table 1.5. Percentage of incident patients (2010) in different ethnic groups by centre

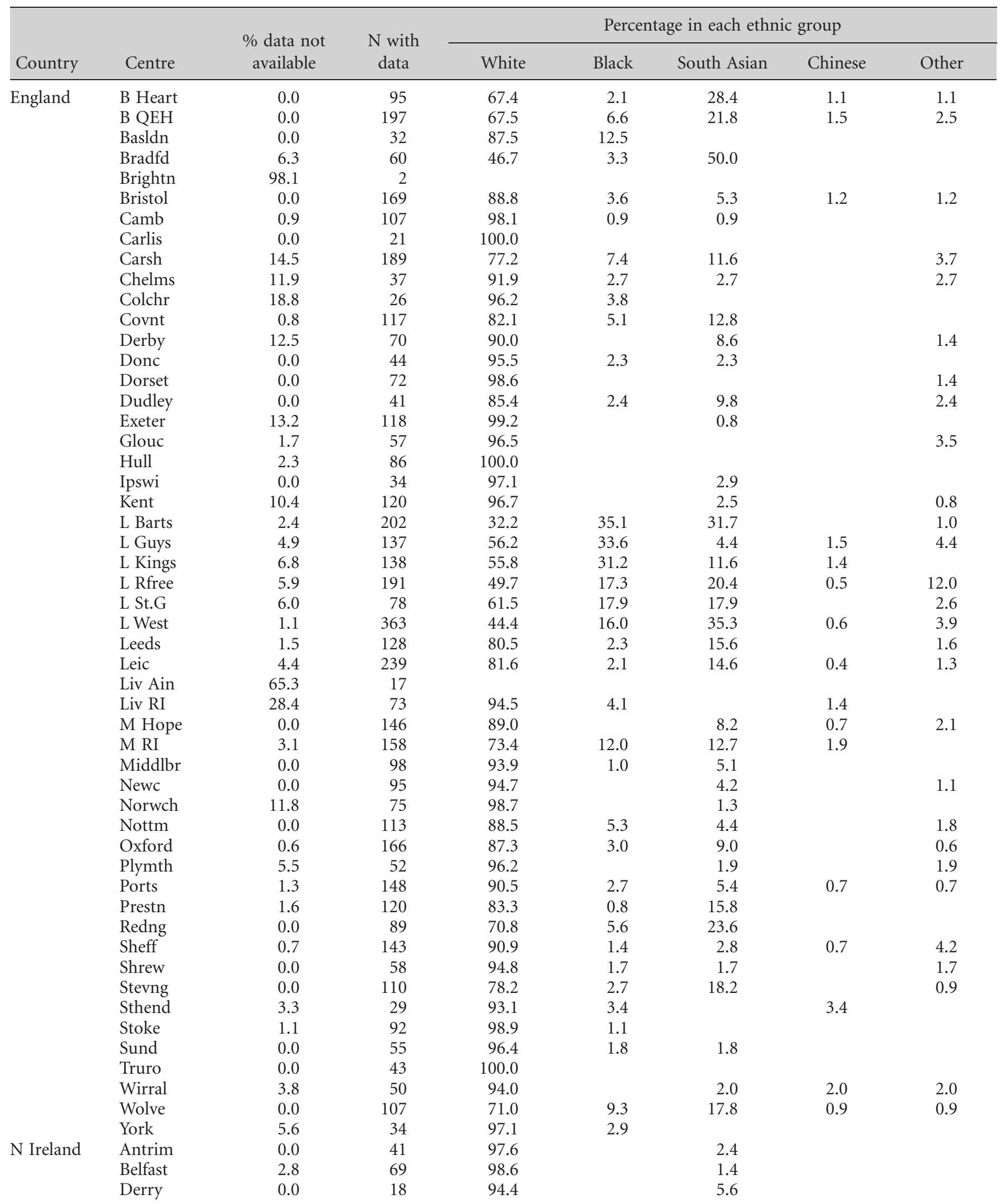


Table 1.5. Continued

\begin{tabular}{|c|c|c|c|c|c|c|c|c|}
\hline Country & Centre & $\begin{array}{c}\% \text { data not } \\
\text { available }\end{array}$ & $\begin{array}{c}\mathrm{N} \text { with } \\
\text { data }\end{array}$ & \multicolumn{5}{|c|}{ Percentage in each ethnic group } \\
\hline & Tyrone & 0.0 & 10 & 100.0 & & & & \\
\hline & Ulster & 0.0 & 20 & 95.0 & & 5.0 & & \\
\hline \multirow[t]{3}{*}{ Wales } & Bangor & 0.0 & 26 & 100.0 & & & & \\
\hline & Swanse & 0.0 & 135 & 98.5 & & 1.5 & & \\
\hline & Wrexm & 0.0 & 24 & 100.0 & & & & \\
\hline England & & 6.2 & 5,241 & 78.1 & 7.4 & 12.3 & 0.5 & 1.8 \\
\hline N Ireland & & 1.1 & 179 & 97.8 & & 2.2 & & \\
\hline Wales & & 1.3 & 381 & 96.1 & 0.8 & 2.6 & & 0.5 \\
\hline E, W \& NI & & 5.7 & 5,801 & 79.8 & 6.8 & 11.3 & 0.4 & 1.7 \\
\hline
\end{tabular}

The percentage breakdown is not shown for centres with less than $50 \%$ data completeness, but these centres are included in national averages

\section{Ethnicity}

In 2010, there was an improvement in the completeness of ethnicity data. Sixty-one centres returned ethnicity data that were $50 \%$ or more complete (table 1.5 ) compared with 51 centres last year. Fifty-two of these 61 centres provided ethnicity data for $90 \%$ or more of their incident patients compared with 27 centres last year. Ethnicity completeness is low in the Scottish Renal Registry and Scotland has not been included in the table. The low completeness for some centres means results should still be interpreted with some caution. There was great variation between centres in the ethnic mix of incident patients ranging from $0 \%$ ethnic minorities in Carlisle, Hull, Truro, Newry, Tyrone,
Bangor, Clywd and Wrexham to over 50\% in Bradford, London Barts, London Royal Free and London West.

\section{Primary renal diagnosis}

The distribution of primary renal disease (PRD) by centre is shown in table 1.6. Data for PRD were missing in $9.8 \%$ of patients and there remained marked differences between centres in completeness of data returns. Sixty centres provided data on over $90 \%$ of incident patients and 28 of these had 100\% completeness. Four centres had missing PRD data for more than $25 \%$ of new patients and for these centres the percentages in the diagnostic categories have not been shown in table 1.6.

Table 1.6. Percentage distribution of primary renal diagnosis by centre in the 2010 incident cohort

\begin{tabular}{|c|c|c|c|c|c|c|c|c|c|c|c|}
\hline \multirow[b]{2}{*}{ Country } & \multirow[b]{2}{*}{ Centre } & \multirow[b]{2}{*}{$\begin{array}{c}\% \\
\text { data not } \\
\text { available }\end{array}$} & \multirow[b]{2}{*}{$\begin{array}{c}\mathrm{N} \\
\text { with } \\
\text { data }\end{array}$} & \multicolumn{8}{|c|}{ Percentage } \\
\hline & & & & $\begin{array}{l}\text { Uncertain } \\
\text { aetiology }^{\text {a }}\end{array}$ & Diabetes & $\begin{array}{l}\text { Glomerulo- } \\
\text { nephritis }\end{array}$ & $\begin{array}{l}\text { Hyper- } \\
\text { tension }\end{array}$ & Other & $\begin{array}{l}\text { Polycystic } \\
\text { kidney }\end{array}$ & $\begin{array}{l}\text { Pyelo- } \\
\text { nephritis }\end{array}$ & $\begin{array}{c}\text { Renal } \\
\text { vascular } \\
\text { disease }\end{array}$ \\
\hline \multirow[t]{14}{*}{ England } & B Heart & 1.1 & 94 & 28.7 & 26.6 & 12.8 & 3.2 & 10.6 & 2.1 & 8.5 & 7.5 \\
\hline & B QEH & 0.0 & 197 & 12.7 & 25.9 & 12.7 & 7.1 & 17.3 & 8.1 & 7.1 & 9.1 \\
\hline & Basldn & 0.0 & 32 & 25.0 & 18.8 & 12.5 & 3.1 & 9.4 & 12.5 & 6.3 & 12.5 \\
\hline & Bradfd & 1.6 & 63 & 23.8 & 36.5 & 9.5 & 9.5 & 7.9 & 3.2 & 4.8 & 4.8 \\
\hline & Brightn & 72.0 & 30 & & & & & & & & \\
\hline & Bristol & 0.6 & 168 & 21.4 & 17.3 & 12.5 & 6.0 & 20.2 & 7.1 & 7.1 & 8.3 \\
\hline & Camb & 0.0 & 108 & 53.7 & & & & & & & \\
\hline & Carlis & 0.0 & 21 & 4.8 & 23.8 & 14.3 & 19.1 & 19.1 & 4.8 & 14.3 & 0.0 \\
\hline & Carsh & 19.0 & 179 & 34.1 & 17.9 & 6.2 & 6.7 & 20.1 & 3.4 & 5.0 & 6.7 \\
\hline & Chelms & 4.8 & 40 & 30.0 & 25.0 & 10.0 & 5.0 & 15.0 & 0.0 & 7.5 & 7.5 \\
\hline & Colchr & 18.8 & 26 & 11.5 & 11.5 & 15.4 & 11.5 & 15.4 & 3.9 & 19.2 & 11.5 \\
\hline & Covnt & 2.5 & 115 & 18.3 & 13.9 & 12.2 & 10.4 & 15.7 & 11.3 & 7.0 & 11.3 \\
\hline & Derby & 2.5 & 78 & 24.4 & 24.4 & 15.4 & 1.3 & 16.7 & 1.3 & 9.0 & 7.7 \\
\hline & Donc & 0.0 & 44 & 43.2 & 25.0 & 2.3 & 6.8 & 11.4 & 4.6 & 4.6 & 2.3 \\
\hline
\end{tabular}


Table 1.6. Continued




Table 1.6. Continued

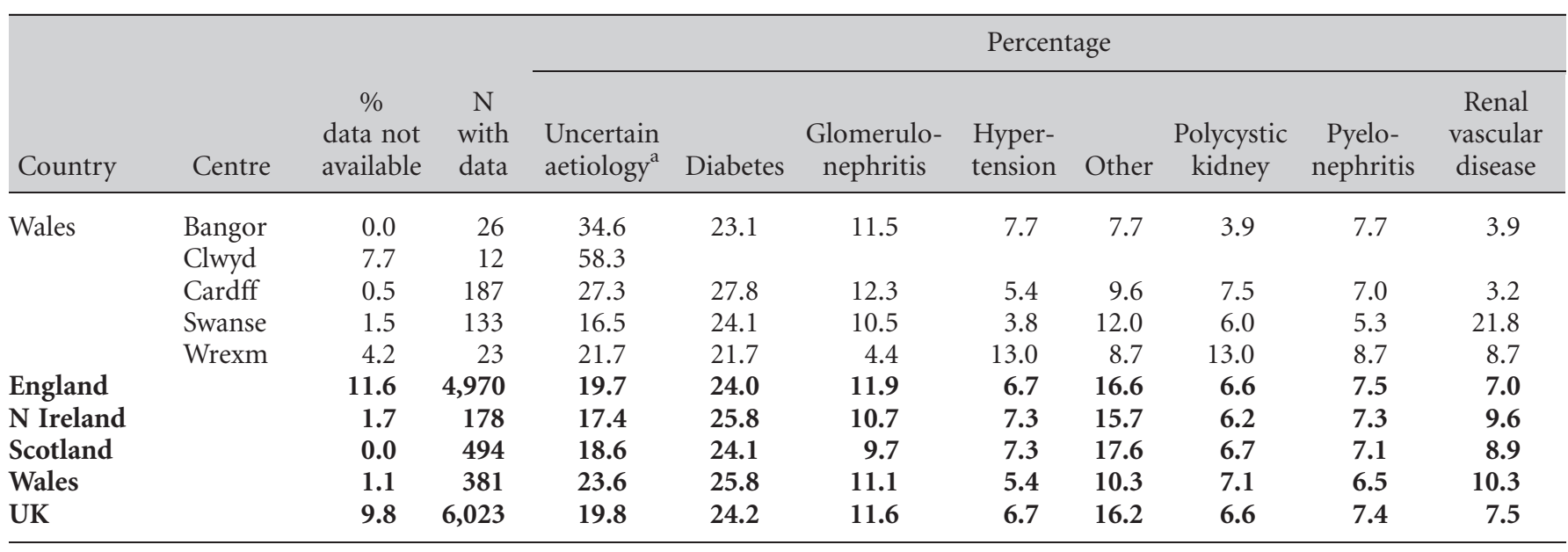

aincludes presumed glomerulonephritis not biopsy proven

The percentage in each category has been calculated after excluding those patients with data not available

For those centres with $>25 \%$ missing primary diagnoses, the percentages in the diagnostic categories have not been calculated

For those centres judged to have high $\%$ uncertain aetiology, the percentages in the other diagnostic categories have not been calculated and the centres have not been included in the country and UK averages

The UKRR continues to be concerned about centres with apparently very high data completeness for PRD but also very high rates of 'uncertain' diagnoses (EDTA codes 00 and 10). It is accepted that there will inevitably be a number of patients with uncertain aetiology and that the proportion of these patients will vary between clinicians and centres as the definitions of renovascular disease, hypertensive nephropathy and chronic glomerulonephritis without tissue diagnosis remain relatively subjective. This year data was not used from five centres which had diagnosis 'unknown' for over $50 \%$ of their incident patients with non-missing data. As the numbers with the specific PRDs are likely to be falsely low in these centres, the breakdown into these categories has not been shown in table 1.6 or used in the country and UK averages. These centres have also been excluded where PRD is used to stratify analyses.
For the non-excluded centres, the overall UK percentage with uncertain aetiology was slightly down on 2009 (19.8\% from $20.7 \%$ ) and again, there was great variation between centres. Some of this variation is likely to reflect the lack of a clear definition of certain diagnostic categories e.g. hypertensive renal disease and renal vascular disease; some may result from differences between centres in attitudes to the degree of certainty required to record other diagnoses.

There was only a small amount of missing data for Northern Ireland and Wales and none for Scotland, whilst England had $11.6 \%$ missing. The overall percentage missing was similar to last year (9.8\% from 9.9\%) and was similar in under and over 65 year olds $(10.0 \%$ and $9.7 \%$ respectively).

The overall distribution of PRDs is shown in table 1.7. Diabetic nephropathy was the most common specific

Table 1.7. Percentage distribution of primary renal diagnosis by age, plus gender ratio, in the 2010 incident cohort

\begin{tabular}{lcccc}
\hline Diagnosis & Age $<65$ & Age $\geqslant 65$ & All patients & M:F \\
\hline Diabetes & 27.0 & 21.3 & 24.2 & 1.8 \\
Glomerulonephritis & 15.8 & 7.3 & 11.6 & 2.1 \\
Pyelonephritis & 7.8 & 7.1 & 7.4 & 2.1 \\
Hypertension & 5.7 & 7.8 & 6.7 & 2.2 \\
Polycystic kidney & 9.8 & 3.5 & 7.5 & 1.0 \\
Renal vascular disease & 1.9 & 13.1 & 16.2 & 2.2 \\
Other $_{\text {Uncertain aetiology }}^{\text {a }}$ & 17.3 & 24.8 & 19.8 & 1.3 \\
\hline
\end{tabular}

includes presumed glomerulonepritis not biopsy proven

Percentages calculated after excluding those patients with data not available 
Table 1.8. Primary renal diagnosis incidence rates per million population (unadjusted) 2010

\begin{tabular}{|c|c|c|c|c|c|}
\hline Diagnosis & England & $\mathrm{N}$ Ireland & Scotland & Wales & UK \\
\hline Diabetes & 22.9 & 25.6 & 22.8 & 33.8 & 23.5 \\
\hline Glomerulonephritis & 11.3 & 10.6 & 9.2 & 14.6 & 11.3 \\
\hline Hypertension & 6.4 & 7.2 & 6.9 & 7.1 & 6.5 \\
\hline Polycystic kidney & 6.3 & 6.1 & 6.3 & 9.3 & 6.5 \\
\hline Renal vascular disease & 6.7 & 9.4 & 8.4 & 13.5 & 7.3 \\
\hline Data not available & 12.6 & 1.7 & 0.0 & 1.4 & 10.6 \\
\hline All & 108 & 101 & 95 & 133 & 108 \\
\hline
\end{tabular}

includes presumed glomerulonephritis not biopsy proven

The overall rates per country may be slightly different to those in table 1.1 as those centres whose PRD data has not been used have been excluded from both the numerator and the denominator here

renal diagnosis in both the under and over 65 year age groups, accounting for $24 \%$ of all (non-missing) incident diagnoses. Biopsy proven glomerulonephritis and autosomal dominant polycystic kidney disease (ADPKD) made up higher proportions of the younger than the older incident cohorts $(16 \%$ vs. $7 \%$ and $10 \%$ vs. $4 \%$ respectively), whilst renal vascular disease was much more common in older incident patients ( $13 \%$ vs. $2 \%)$. It was perhaps not surprising that uncertainty about the underlying diagnosis was also more common in the older cohort ( $25 \%$ vs. $15 \%)$.

For all primary renal diagnoses except ADPKD, the male to female ratio was 1.3 or greater. This gender difference may relate to factors such as hypertension, atheroma and renal vascular disease and smoking which are more common in males and may influence the rate of progression of renal failure.

Table 1.8 shows the incidence rates for each PRD per million population in the 2010 cohort by country. As there were some missing data, the rates for at least some of the diagnoses will be underestimates.

\section{First established treatment modality}

The first treatment recorded, irrespective of any later change, was haemodialysis (HD) in $74.8 \%$ of patients, peritoneal dialysis (PD) in $18.3 \%$ and pre-emptive transplant in $6.9 \%$ in 2010. This is a small decrease for HD (76.3 to 74.8) and an increase for PD (17.9 to 18.3) and transplant (5.9 to 6.9) since 2009.

Many patients, especially those presenting late, undergo a brief period of HD before switches to other modalities are, or can be, considered. Hence, the established modality at 90 days is more representative of the elective first modality. By 90 days, 5.6\% of the 2010 inci- dent patients had died and a further $0.3 \%$ had stopped treatment, leaving $94.1 \%$ of the original cohort still on RRT. Table 1.9 shows the percentages on each treatment modality at 90 days both as percentages of all of those starting RRT and then of those still on treatment at 90 days. For this analysis, the incident cohort from 1st October 2009 to 30th September 2010 was used so that follow up to 90 days was available for all patients. Expressed as percentages of the whole incident cohort, $68.3 \%$ were on HD at 90 days, $18.1 \%$ were on PD and $7.7 \%$ had received a transplant. Expressed as a percentage of those still receiving RRT at 90 days, $72.6 \%$ were on HD, $19.2 \%$ on PD and $8.1 \%$ had received a transplant. Figure 1.8 shows these percentages with the HD patients further subdivided. Of those still on RRT at 90 days, $46.1 \%$ were treated with main centre HD and 26.2\% with satellite HD. The percentage of patients receiving peritoneal dialysis at 90 days increased from the previous year for the first time since the start of the Renal Registry.

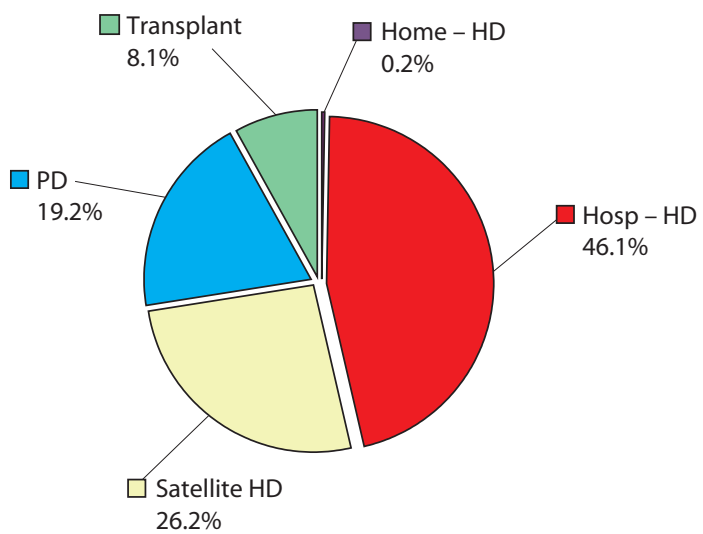

Fig. 1.8. RRT modality at day 90 (incident cohort $1 / 10 / 2009$ to 30/09/2010) 
Northern Ireland continued to have the lowest percentage of patients on PD at 90 days.

The percentage of incident patients who had died by 90 days varied considerably between centres $(0 \%$ to $19 \%$, table 1.9). Differences in the definition of whether patients have acute or chronic renal failure may be a factor in this apparent variation alongside possible differences in clinical practice.

The percentage with a functioning transplant at 90 days in different centres varied between $0 \%$ and $22 \%$. The mean percentage of the incident cohort with a functioning transplant by 90 days was significantly greater in transplanting compared to non-transplanting centres $(10.5 \%$ vs. $5.0 \%$ : $\mathrm{p}<0.0001)$. One possible reason could be that some patients transplanted pre-emptively were attributed to the incident cohort of the transplanting centre rather than that of the referring centre (as mentioned earlier) and this was particularly the case in Reading, Oxford, Carlisle and Newcastle.

Table 1.10 shows the HD/PD split for those incident patients on dialysis at 90 days. It also gives this split by age group. The percentage on PD at 90 days was twice as high in patients aged $<65$ years than in older patients $(28.2 \%$ vs. $14.0 \%)$. The median age on HD was 67.4 years compared with 58.4 years for PD. There were however four centres where the percentage of patients treated with PD was higher in the over $65 \mathrm{~s}$ than the under 65s (Cambridge, Dorset, Liverpool Aintree and Truro).

\section{Renal function at the time of starting RRT}

Some caution should be applied to the analysis of eGFR at the start of RRT. A review of pre-RRT biochemistry in nine renal centres revealed that up to $18 \%$ of patients may have an incorrect date of start of RRT allocated (by up to 5 weeks). In these patients, the eGFR used for analysis in some patients may have been taken whilst they were already receiving RRT and thus be artificially high. The details of this analysis and a subsequent validation study were described in detail in the 12th Annual Report chapter 13: The UK Renal Registry Advanced CKD Study 2009 [5].

Table 1.9. RRT modality at 90 days by centre (incident cohort $1 / 10 / 2009$ to $30 / 09 / 2010$ )

\begin{tabular}{|c|c|c|c|c|c|c|c|c|c|c|}
\hline \multirow[b]{2}{*}{ Country } & \multirow[b]{2}{*}{ Centre } & \multirow[b]{2}{*}{$\mathrm{N}$} & \multicolumn{5}{|c|}{ Percentage of patients who started RRT } & \multicolumn{3}{|c|}{$\begin{array}{c}\text { Percentage of patients still on } \\
\text { RRT at } 90 \text { days }\end{array}$} \\
\hline & & & HD & $\mathrm{PD}$ & $\mathrm{Tx}$ & $\begin{array}{l}\text { Stopped } \\
\text { treatment }\end{array}$ & Died & HD & $\mathrm{PD}$ & $\mathrm{Tx}$ \\
\hline \multirow[t]{25}{*}{ England } & B Heart & 97 & 77.3 & 15.5 & 5.2 & 0.0 & 2.1 & 79.0 & 15.8 & 5.3 \\
\hline & B QEH & 214 & 73.4 & 15.9 & 8.4 & 0.0 & 2.3 & 75.1 & 16.3 & 8.6 \\
\hline & Basldn & 32 & 68.8 & 12.5 & 0.0 & 0.0 & 18.8 & 84.6 & 15.4 & 0.0 \\
\hline & Bradfd & 56 & 73.2 & 12.5 & 3.6 & 0.0 & 10.7 & 82.0 & 14.0 & 4.0 \\
\hline & Brightn & 127 & 66.9 & 26.0 & 0.8 & 0.0 & 6.3 & 71.4 & 27.7 & 0.8 \\
\hline & Bristol & 170 & 72.9 & 11.8 & 8.8 & 0.0 & 6.5 & 78.0 & 12.6 & 9.4 \\
\hline & Camb & 99 & 61.6 & 12.1 & 22.2 & 0.0 & 4.0 & 64.2 & 12.6 & 23.2 \\
\hline & Carlis & 24 & 66.7 & 25.0 & 8.3 & 0.0 & 0.0 & 66.7 & 25.0 & 8.3 \\
\hline & Carsh & 225 & 79.6 & 8.9 & 6.7 & 0.0 & 4.9 & 83.6 & 9.4 & 7.0 \\
\hline & Chelms & 47 & 51.1 & 40.4 & 4.3 & 2.1 & 2.1 & 53.3 & 42.2 & 4.4 \\
\hline & Colchr & 25 & 88.0 & 0.0 & 4.0 & 0.0 & 8.0 & 95.7 & 0.0 & 4.4 \\
\hline & Covnt & 110 & 65.5 & 19.1 & 7.3 & 0.0 & 8.2 & 71.3 & 20.8 & 7.9 \\
\hline & Derby & 73 & 46.6 & 41.1 & 1.4 & 1.4 & 9.6 & 52.3 & 46.2 & 1.5 \\
\hline & Donc & 45 & 68.9 & 20.0 & 0.0 & 0.0 & 11.1 & 77.5 & 22.5 & 0.0 \\
\hline & Dorset & 65 & 64.6 & 20.0 & 10.8 & 1.5 & 3.1 & 67.7 & 21.0 & 11.3 \\
\hline & Dudley & 46 & 65.2 & 28.3 & 0.0 & 0.0 & 6.5 & 69.8 & 30.2 & 0.0 \\
\hline & Exeter & 134 & 71.6 & 17.9 & 2.2 & 0.8 & 7.5 & 78.1 & 19.5 & 2.4 \\
\hline & Glouc & 55 & 76.4 & 14.6 & 3.6 & 0.0 & 5.5 & 80.8 & 15.4 & 3.9 \\
\hline & Hull & 102 & 71.6 & 18.6 & 1.0 & 0.0 & 8.8 & 78.5 & 20.4 & 1.1 \\
\hline & Ipswi & 33 & 63.6 & 24.2 & 12.1 & 0.0 & 0.0 & 63.6 & 24.2 & 12.1 \\
\hline & Kent & 135 & 62.2 & 15.6 & 11.1 & 0.7 & 10.4 & 70.0 & 17.5 & 12.5 \\
\hline & L Barts & 226 & 60.6 & 27.4 & 7.1 & 0.0 & 4.9 & 63.7 & 28.8 & 7.4 \\
\hline & L Guys & 165 & 64.9 & 10.9 & 21.2 & 0.0 & 3.0 & 66.9 & 11.3 & 21.9 \\
\hline & L Kings & 135 & 63.7 & 31.1 & 1.5 & 0.0 & 3.7 & 66.2 & 32.3 & 1.5 \\
\hline & L Rfree & 202 & 71.3 & 10.4 & 16.3 & 0.0 & 2.0 & 72.7 & 10.6 & 16.7 \\
\hline
\end{tabular}


Table 1.9. Continued

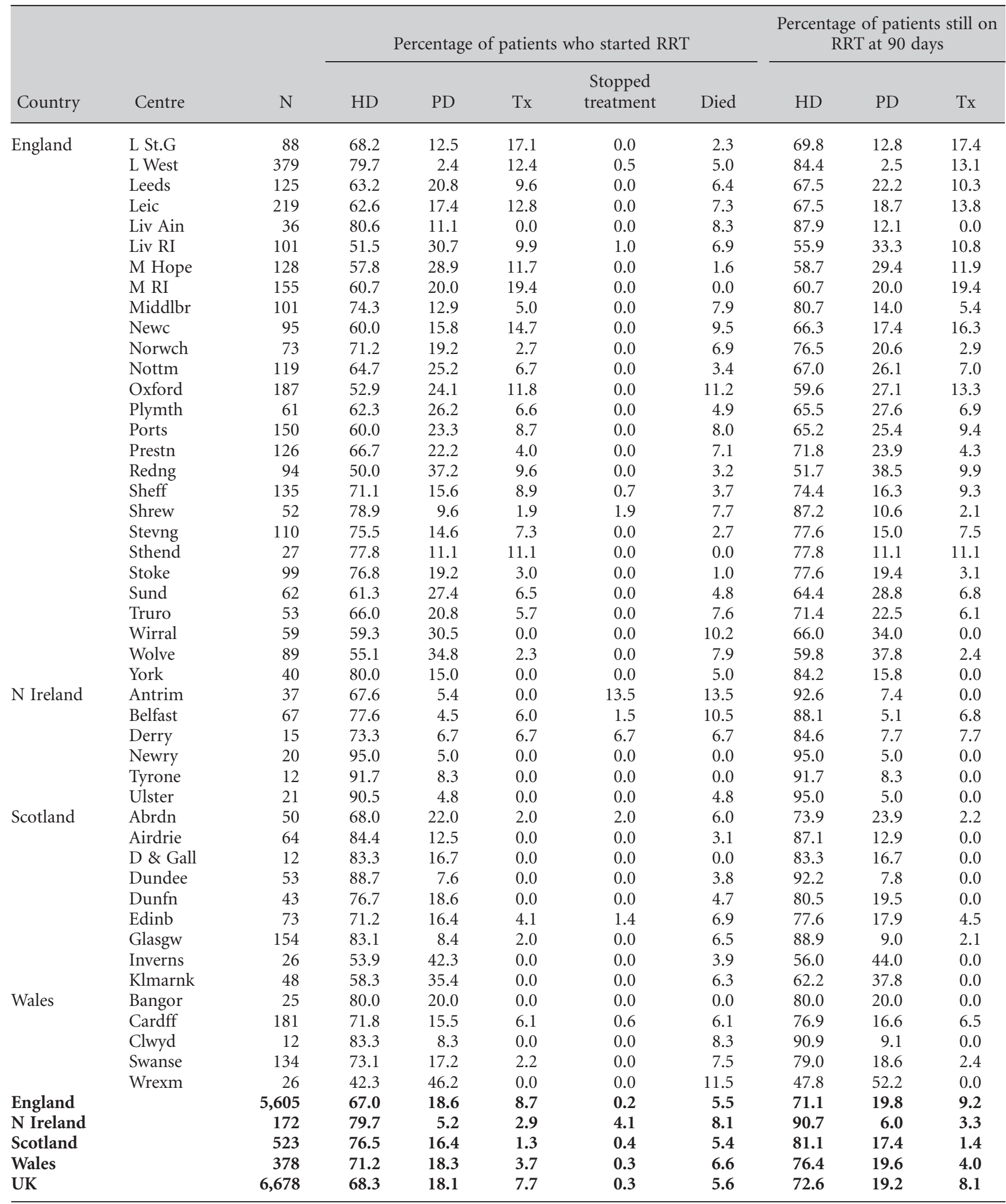






Fig. 1.9. Geometric mean eGFR at start of RRT (2010) by age group

The mean eGFR at initiation of RRT in 2010 was $8.7 \mathrm{ml} / \mathrm{min} / 1.73 \mathrm{~m}^{2}$. This was highest in patients who were aged 85 and over, at $9.1 \mathrm{ml} / \mathrm{min} / 1.73 \mathrm{~m}^{2}$ (figure 1.9). By contrast, in the United States $54 \%$ of patients starting RRT in 2009 had an eGFR greater than $10 \mathrm{ml} / \mathrm{min} / 1.73 \mathrm{~m}^{2}[6]$.

Figure 1.10 shows serial data from centres reporting annually to the UKRR since 1999. It demonstrates a continued pattern over the last six years of a higher mean eGFR at start of RRT for PD than HD patients. In patients starting $\mathrm{HD}$, there may be some plateauing of this level around an eGFR of $8.5 \mathrm{ml} / \mathrm{min} / 1.73 \mathrm{~m}^{2}$.

\section{Late presentation and delayed referral of incident patients}

\section{Introduction}

Late presentation to a nephrologist has many definitions and a range of possible causes. There are many patients with chronic kidney disease who are regularly monitored in primary or secondary care and whose referral to nephrology services is delayed (delayed or late referral). In contrast other patients present late to medical services. Chronic kidney disease may be asymptomatic until very advanced resulting in no contact with medical services or patients may present with a variety of rapidly progressive kidney diseases: these patients are the true 'late presenters'. The main analyses presented here do not differentiate between these groups and include any patient first seen by renal services within 90 days of starting RRT as 'late presentation' however this year we have also attempted to capture late referrals by

Table 1.10. Modality split of patients on dialysis at 90 days after starting RRT (1/10/2009 to 30/09/2010)

\begin{tabular}{|c|c|c|c|c|c|c|c|c|}
\hline \multirow[b]{2}{*}{ Country } & \multirow[b]{2}{*}{ Centre } & \multirow[b]{2}{*}{$\mathrm{N}$} & \multicolumn{2}{|c|}{ Age <65 (\%) } & \multicolumn{2}{|c|}{ Age $\geqslant 65(\%)$} & \multicolumn{2}{|c|}{ All patients (\%) } \\
\hline & & & HD & $\mathrm{PD}$ & HD & $\mathrm{PD}$ & HD & PD \\
\hline \multirow{23}{*}{ England } & B Heart & 90 & 74.5 & 25.5 & 93.0 & 7.0 & 83.3 & 16.7 \\
\hline & B QEH & 191 & 70.7 & 29.3 & 94.6 & 5.4 & 82.2 & 17.8 \\
\hline & Basldn & 26 & 80.0 & 20.0 & 87.5 & 12.5 & 84.6 & 15.4 \\
\hline & Bradfd & 48 & 70.8 & 29.2 & 100.0 & 0.0 & 85.4 & 14.6 \\
\hline & Brightn & 118 & 65.3 & 34.7 & 76.8 & 23.2 & 72.0 & 28.0 \\
\hline & Bristol & 144 & 79.5 & 20.5 & 93.0 & 7.0 & 86.1 & 13.9 \\
\hline & Camb & 73 & 84.0 & 16.0 & 83.3 & 16.7 & 83.6 & 16.4 \\
\hline & Carlis & 22 & 54.5 & 45.5 & 90.9 & 9.1 & 72.7 & 27.3 \\
\hline & Carsh & 199 & 85.0 & 15.0 & 93.3 & 6.7 & 89.9 & 10.1 \\
\hline & Chelms & 43 & 33.3 & 66.7 & 84.2 & 15.8 & 55.8 & 44.2 \\
\hline & Colchr & 22 & 100.0 & 0.0 & 100.0 & 0.0 & 100.0 & 0.0 \\
\hline & Covnt & 93 & 70.5 & 29.5 & 83.7 & 16.3 & 77.4 & 22.6 \\
\hline & Derby & 64 & 34.5 & 65.5 & 68.6 & 31.4 & 53.1 & 46.9 \\
\hline & Donc & 40 & 68.4 & 31.6 & 85.7 & 14.3 & 77.5 & 22.5 \\
\hline & Dorset & 55 & 81.8 & 18.2 & 72.7 & 27.3 & 76.4 & 23.6 \\
\hline & Dudley & 43 & 44.4 & 55.6 & 88.0 & 12.0 & 69.8 & 30.2 \\
\hline & Exeter & 120 & 74.4 & 25.6 & 82.7 & 17.3 & 80.0 & 20.0 \\
\hline & Glouc & 50 & 65.0 & 35.0 & 96.7 & 3.3 & 84.0 & 16.0 \\
\hline & Hull & 92 & 76.9 & 23.1 & 81.1 & 18.9 & 79.3 & 20.7 \\
\hline & Ipswi & 29 & 57.1 & 42.9 & 86.7 & 13.3 & 72.4 & 27.6 \\
\hline & Kent & 105 & 66.7 & 33.3 & 90.0 & 10.0 & 80.0 & 20.0 \\
\hline & L Barts & 199 & 64.8 & 35.2 & 78.9 & 21.1 & 68.8 & 31.2 \\
\hline & L Guys & 125 & 84.8 & 15.2 & 87.0 & 13.0 & 85.6 & 14.4 \\
\hline
\end{tabular}


Table 1.10. Continued

\begin{tabular}{|c|c|c|c|c|c|c|c|c|}
\hline \multirow[b]{2}{*}{ Country } & \multirow[b]{2}{*}{ Centre } & \multirow[b]{2}{*}{$\mathrm{N}$} & \multicolumn{2}{|c|}{ Age $<65(\%)$} & \multicolumn{2}{|c|}{ Age $\geqslant 65(\%)$} & \multicolumn{2}{|c|}{ All patients (\%) } \\
\hline & & & HD & PD & HD & $\mathrm{PD}$ & HD & $\mathrm{PD}$ \\
\hline \multirow[t]{29}{*}{ England } & L Kings & 128 & 65.7 & 34.3 & 69.0 & 31.0 & 67.2 & 32.8 \\
\hline & L Rfree & 165 & 83.5 & 16.5 & 90.7 & 9.3 & 87.3 & 12.7 \\
\hline & L St.G & 71 & 78.6 & 21.4 & 88.4 & 11.6 & 84.5 & 15.5 \\
\hline & L West & 311 & 96.4 & 3.6 & 97.9 & 2.1 & 97.1 & 2.9 \\
\hline & Leeds & 105 & 64.0 & 36.0 & 85.5 & 14.5 & 75.2 & 24.8 \\
\hline & Leic & 175 & 73.5 & 26.5 & 82.6 & 17.4 & 78.3 & 21.7 \\
\hline & Liv Ain & 33 & 88.9 & 11.1 & 86.7 & 13.3 & 87.9 & 12.1 \\
\hline & Liv RI & 83 & 51.1 & 48.9 & 77.8 & 22.2 & 62.7 & 37.3 \\
\hline & M Hope & 111 & 64.6 & 35.4 & 69.6 & 30.4 & 66.7 & 33.3 \\
\hline & M RI & 125 & 66.7 & 33.3 & 83.1 & 16.9 & 75.2 & 24.8 \\
\hline & Middlbr & 88 & 71.4 & 28.6 & 94.3 & 5.7 & 85.2 & 14.8 \\
\hline & Newc & 72 & 71.4 & 28.6 & 86.5 & 13.5 & 79.2 & 20.8 \\
\hline & Norwch & 66 & 75.0 & 25.0 & 81.0 & 19.0 & 78.8 & 21.2 \\
\hline & Nottm & 107 & 62.5 & 37.5 & 82.4 & 17.6 & 72.0 & 28.0 \\
\hline & Oxford & 144 & 59.7 & 40.3 & 79.1 & 20.9 & 68.8 & 31.3 \\
\hline & Plymth & 54 & 62.5 & 37.5 & 76.7 & 23.3 & 70.4 & 29.6 \\
\hline & Ports & 125 & 66.2 & 33.8 & 78.3 & 21.7 & 72.0 & 28.0 \\
\hline & Prestn & 112 & 70.3 & 29.7 & 81.3 & 18.8 & 75.0 & 25.0 \\
\hline & Redng & 82 & 47.8 & 52.2 & 69.4 & 30.6 & 57.3 & 42.7 \\
\hline & Sheff & 117 & 75.8 & 24.2 & 90.2 & 9.8 & 82.1 & 17.9 \\
\hline & Shrew & 46 & 88.9 & 11.1 & 89.3 & 10.7 & 89.1 & 10.9 \\
\hline & Stevng & 99 & 78.3 & 21.7 & 92.3 & 7.7 & 83.8 & 16.2 \\
\hline & Sthend & 24 & 77.8 & 22.2 & 93.3 & 6.7 & 87.5 & 12.5 \\
\hline & Stoke & 95 & 70.6 & 29.4 & 85.2 & 14.8 & 80.0 & 20.0 \\
\hline & Sund & 55 & 57.6 & 42.4 & 86.4 & 13.6 & 69.1 & 30.9 \\
\hline & Truro & 46 & 83.3 & 16.7 & 71.4 & 28.6 & 76.1 & 23.9 \\
\hline & Wirral & 53 & 46.7 & 53.3 & 91.3 & 8.7 & 66.0 & 34.0 \\
\hline & Wolve & 80 & 52.4 & 47.6 & 71.1 & 28.9 & 61.3 & 38.8 \\
\hline & York & 38 & 81.8 & 18.2 & 87.5 & 12.5 & 84.2 & 15.8 \\
\hline \multirow[t]{6}{*}{$\mathrm{N}$ Ireland } & Antrim & 27 & 85.7 & 14.3 & 100.0 & 0.0 & 92.6 & 7.4 \\
\hline & Belfast & 55 & 91.3 & 8.7 & 96.9 & 3.1 & 94.5 & 5.5 \\
\hline & Derry & 12 & 83.3 & 16.7 & 100.0 & 0.0 & 91.7 & 8.3 \\
\hline & Newry & 20 & 100.0 & 0.0 & 88.9 & 11.1 & 95.0 & 5.0 \\
\hline & Tyrone & 12 & 75.0 & 25.0 & 100.0 & 0.0 & 91.7 & 8.3 \\
\hline & Ulster & 20 & 80.0 & 20.0 & 100.0 & 0.0 & 95.0 & 5.0 \\
\hline \multirow[t]{9}{*}{ Scotland } & Abrdn & 45 & 64.5 & 35.5 & 100.0 & 0.0 & 75.6 & 24.4 \\
\hline & Airdrie & 62 & 82.9 & 17.1 & 92.6 & 7.4 & 87.1 & 12.9 \\
\hline & D \& Gall & 12 & 75.0 & 25.0 & 87.5 & 12.5 & 83.3 & 16.7 \\
\hline & Dundee & 51 & 80.0 & 20.0 & 100.0 & 0.0 & 92.2 & 7.8 \\
\hline & Dunfn & 41 & 73.3 & 26.7 & 84.6 & 15.4 & 80.5 & 19.5 \\
\hline & Edinb & 64 & 79.4 & 20.6 & 83.3 & 16.7 & 81.3 & 18.8 \\
\hline & Glasgw & 141 & 87.0 & 13.0 & 94.4 & 5.6 & 90.8 & 9.2 \\
\hline & Inverns & 25 & 33.3 & 66.7 & 90.0 & 10.0 & 56.0 & 44.0 \\
\hline & Klmarnk & 45 & 57.1 & 42.9 & 66.7 & 33.3 & 62.2 & 37.8 \\
\hline \multirow[t]{5}{*}{ Wales } & Bangor & 25 & 80.0 & 20.0 & 80.0 & 20.0 & 80.0 & 20.0 \\
\hline & Cardff & 158 & 74.2 & 25.8 & 88.0 & 12.0 & 82.3 & 17.7 \\
\hline & Clwyd & 11 & 75.0 & 25.0 & 100.0 & 0.0 & 90.9 & 9.1 \\
\hline & Swanse & 121 & 71.7 & 28.3 & 86.7 & 13.3 & 81.0 & 19.0 \\
\hline & Wrexm & 23 & 12.5 & 87.5 & 66.7 & 33.3 & 47.8 & 52.2 \\
\hline England & & 4,801 & 71.1 & 28.9 & 85.3 & 14.7 & 78.3 & 21.7 \\
\hline N Ireland & & 146 & 88.9 & 11.1 & 97.6 & 2.4 & 93.8 & 6.2 \\
\hline Scotland & & 486 & 75.0 & 25.0 & 89.7 & 10.3 & 82.3 & 17.7 \\
\hline Wales & & 338 & 70.1 & 29.9 & 85.8 & 14.2 & 79.6 & 20.4 \\
\hline UK & & 5,771 & 71.8 & 28.2 & 86.0 & 14.0 & 79.1 & 20.9 \\
\hline
\end{tabular}




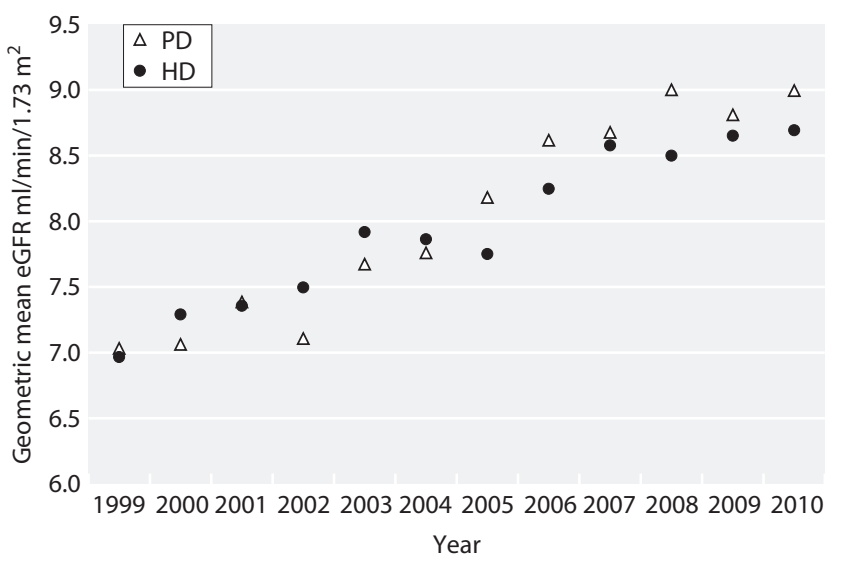

Fig. 1.10. eGFR on starting RRT 1999-2010; PD and HD (restricted to centres reporting since 1999)

excluding an acute renal disease group including all those conditions likely to present with rapidly deteriorating renal function: crescentic glomerulonephritis (type I, II, III), nephropathy (interstitial) due to cis-platinum, renal vascular disease due to malignant hypertension, renal vascular disease due to polyarteritis, Wegener's granulomatosis, cryoglobulinemic glomerulonephritis, myelomatosis/light chain deposit disease, Goodpasture's Syndrome, systemic sclerosis, haemolytic ureaemic syndrome (including Moschcowitz syndrome), multisystem disease - other, tubular necrosis (irreversible) or cortical necrosis, Balkan nephropathy, kidney tumour and traumatic or surgical loss of kidney.

\section{Methods}

Data were included from all incident patients in the years 2009 to 2010 . The date first seen in a renal centre and the date of starting RRT were used to define the late presenting cohort. A small amount of data were excluded because of actual or potential inconsistencies. Only data from those centres/years with $75 \%$ or more completeness were used. Data were excluded for centres in the years where $10 \%$ or more of the patients were reported to have started RRT on the same date as the first presentation, as investigation has shown that this is likely due to misunderstanding on the part of the renal centres resulting in incorrect recording of data. After these exclusions, data on 6,895 patients were available for analysis. Presentation times of 90 days or more were defined as early presentation and times of less than 90 days were defined as late presentation.

\section{Results}

Table 1.11 shows the percentage completeness of data from 2009 to 2010 excluding centres/years with $10 \%$ or more start dates for RRT being on the same day as first presentation. There has been a big improvement in the reporting of presentation time data. Two years of data were combined in most of the following analyses in order to make the late presentation percentages more reliably estimated and to allow these to be shown for specific groups of patients. The improvement in completeness has allowed us to use only two years rather than the six years used in previous reports.

\section{Late presentation by centre}

Late presentation ranged by centre from $3.5-30.0 \%$ in patients commencing RRT in 2009 to 2010 . The overall rate of late presentation was $20.0 \%$ and was $15.2 \%$ once diseases likely to present acutely were excluded.

Table 1.11. Percentage completeness of presentation time data (2009 to 2010) by centre

\begin{tabular}{|c|c|c|c|c|c|}
\hline \multirow[b]{2}{*}{ Country } & \multirow[b]{2}{*}{ Centre } & \multicolumn{2}{|c|}{$\mathrm{N}$ incident patients } & \multicolumn{2}{|c|}{ Percentage completeness } \\
\hline & & 2009 & 2010 & 2009 & 2010 \\
\hline \multirow{13}{*}{ England } & B Heart & 99 & 95 & 4.0 & 95.8 \\
\hline & B QEH & 255 & 197 & 83.7 & 88.3 \\
\hline & Basldn & 26 & 32 & a & 93.8 \\
\hline & Bradfd & 61 & 64 & 91.7 & 100.0 \\
\hline & Brightn & 120 & 107 & 0.8 & 1.9 \\
\hline & Bristol & 158 & 169 & 72.2 & 97.6 \\
\hline & Camb & 136 & 108 & 39.0 & 99.1 \\
\hline & Carlis & 24 & 21 & 83.3 & a \\
\hline & Carsh & 208 & 221 & 0.0 & 86.8 \\
\hline & Chelms & 52 & 42 & 98.1 & 97.6 \\
\hline & Colchr & 17 & 32 & 0.0 & 84.4 \\
\hline & Covnt & 118 & 118 & 0.0 & 95.7 \\
\hline & Derby & 78 & 80 & 97.4 & 98.8 \\
\hline
\end{tabular}


Table 1.11. Continued

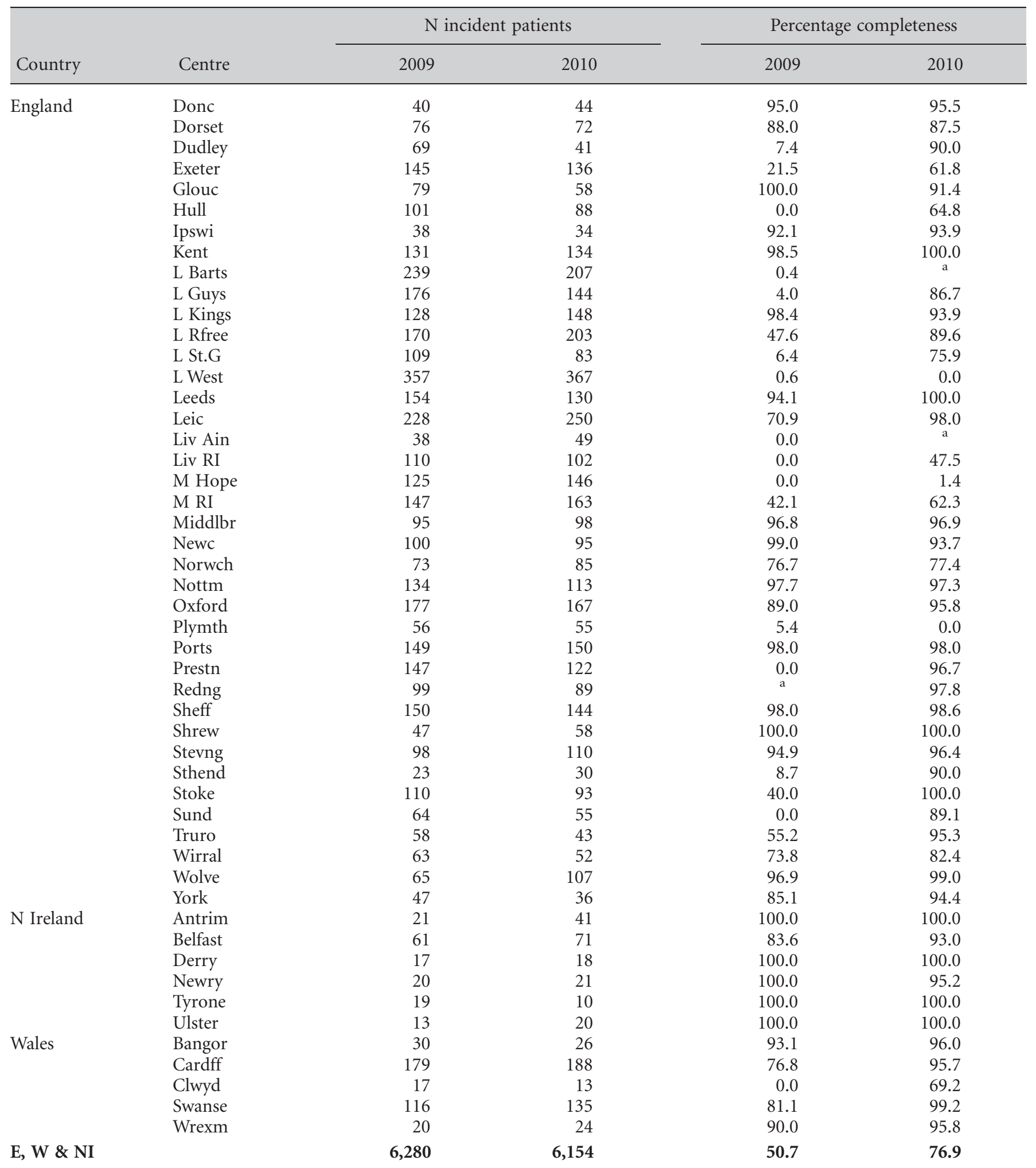

ada not shown as $>10 \%$ of patients reported as starting RRT on the same date as first presentation

Date first seen by a nephrologist has not been collected from the Scottish Renal Registry and so Scottish centres were excluded from these analyses 
Table 1.12 shows the overall percentage presenting late for the combined 2009-2010 incident cohort, the percentages presenting late amongst those patients defined as not having an acute diagnosis and the percentages amongst non-diabetics (as PRD).

Late presentation in 2010 and trend over time

There has been a steady decline nationally in the proportion of patients presenting late to renal services, with some centres achieving $<10 \%$ late presentation rates. This may have been as a consequence of the National CKD guidelines published by the Medical and GP Royal Colleges [7], the Quality and Outcomes Framework (QOF) initiative (www.dh.gov.uk) raising awareness of CKD amongst non-nephrologists and the introduction of estimated GFR reporting.

In 2010,65.8\% of incident patients presented over a year before they needed to start RRT. There were $8.7 \%$

Table 1.12 Percentage of patients presenting to a nephrologist less than 90 days before RRT initiation (2009-2010 incident patients)

\begin{tabular}{|c|c|c|c|c|c|c|}
\hline \multirow[b]{2}{*}{ Country } & \multirow[b]{2}{*}{ Centre } & \multirow[b]{2}{*}{$\mathrm{N}$ with data } & \multicolumn{4}{|c|}{ Percentage presenting late } \\
\hline & & & Overall & $(95 \% \mathrm{CI})$ & Non-acute $^{a}$ & Non-diab PRD \\
\hline \multirow[t]{42}{*}{ England } & B Heart & 91 & 9.9 & $(5.2-17.9)$ & 9.6 & 13.6 \\
\hline & B QEH & 383 & 16.5 & $(13.1-20.5)$ & 13.7 & 17.0 \\
\hline & Basldn & 30 & 30.0 & $(16.4-48.3)$ & 30.0 & 33.3 \\
\hline & Bradfd & 118 & 17.0 & $(11.2-24.8)$ & 13.5 & 18.8 \\
\hline & Bristol & 161 & 22.4 & $(16.6-29.4)$ & 17.9 & 24.8 \\
\hline & Camb & 107 & 22.4 & $(15.5-31.3)$ & & \\
\hline & Carlis & 20 & 25.0 & $(10.8-47.8)$ & 21.1 & 33.3 \\
\hline & Carsh & 190 & 30.0 & $(23.9-36.9)$ & 23.2 & 33.5 \\
\hline & Chelms & 92 & 21.7 & $(14.5-31.3)$ & 17.1 & 25.0 \\
\hline & Colchr & 27 & 25.9 & $(12.9-45.3)$ & 26.1 & 29.2 \\
\hline & Covnt & 112 & 17.9 & $(11.8-26.1)$ & 13.0 & 18.6 \\
\hline & Derby & 155 & 23.9 & $(17.8-31.2)$ & 16.2 & 27.8 \\
\hline & Donc & 80 & 18.8 & $(11.6-28.8)$ & 13.3 & 24.6 \\
\hline & Dorset & 129 & 21.7 & $(15.4-29.6)$ & 15.5 & 25.0 \\
\hline & Dudley & 36 & 13.9 & $(5.9-29.3)$ & 13.9 & 16.0 \\
\hline & Glouc & 129 & 18.6 & $(12.8-26.3)$ & 12.7 & 20.5 \\
\hline & Ipswi & 66 & 30.3 & $(20.5-42.4)$ & 24.2 & 25.9 \\
\hline & Kent & 263 & 28.9 & $(23.7-34.7)$ & 22.2 & 31.8 \\
\hline & L Guys & 124 & 14.5 & $(9.3-21.9)$ & 13.5 & 16.2 \\
\hline & L Kings & 265 & 24.2 & $(19.4-29.7)$ & 18.9 & 29.5 \\
\hline & L Rfree & 181 & 26.5 & $(20.6-33.4)$ & 22.5 & 26.9 \\
\hline & L St.G & 63 & 25.4 & $(16.2-37.5)$ & 17.9 & 29.2 \\
\hline & Leeds & 272 & 18.0 & $(13.9-23.0)$ & 13.8 & 21.3 \\
\hline & Leic & 239 & 14.2 & $(10.3-19.3)$ & 8.6 & 16.3 \\
\hline & Middlbr & 187 & 23.0 & $(17.5-29.6)$ & 16.8 & 21.9 \\
\hline & Newc & 187 & 19.3 & $(14.2-25.5)$ & 14.0 & 23.3 \\
\hline & Norwch & 121 & 19.8 & $(13.7-27.9)$ & 13.3 & 22.7 \\
\hline & Nottm & 234 & 18.0 & $(13.5-23.4)$ & 14.6 & 21.3 \\
\hline & Oxford & 313 & 16.6 & $(12.9-21.2)$ & 13.0 & 20.0 \\
\hline & Ports & 289 & 15.6 & $(11.8-20.2)$ & 12.7 & 18.4 \\
\hline & Prestn & 117 & 21.4 & $(14.9-29.7)$ & 15.8 & 24.0 \\
\hline & Redng & 87 & 12.6 & $(7.1-21.4)$ & 9.5 & 14.9 \\
\hline & Sheff & 288 & 17.0 & $(13.1-21.8)$ & 11.4 & 20.7 \\
\hline & Shrew & 105 & 22.9 & $(15.8-31.9)$ & 15.6 & 27.2 \\
\hline & Stevng & 199 & 15.1 & $(10.8-20.7)$ & 11.8 & 20.1 \\
\hline & Sthend & 27 & 11.1 & $(3.6-29.3)$ & 9.1 & 13.0 \\
\hline & Stoke & 93 & 28.0 & $(19.8-37.9)$ & 24.3 & 30.4 \\
\hline & Sund & 49 & 28.6 & $(17.7-42.6)$ & 23.8 & 32.4 \\
\hline & Truro & 41 & 24.4 & $(13.7-39.7)$ & 21.1 & 32.3 \\
\hline & Wirral & 42 & 26.2 & $(15.1-41.4)$ & 21.4 & 30.6 \\
\hline & Wolve & 166 & 23.5 & $(17.7-30.5)$ & 19.5 & 28.2 \\
\hline & York & 74 & 20.3 & $(12.6-30.9)$ & 10.7 & 25.9 \\
\hline
\end{tabular}


Table 1.12 Continued

\begin{tabular}{|c|c|c|c|c|c|c|}
\hline \multirow[b]{2}{*}{ Country } & \multirow[b]{2}{*}{ Centre } & \multirow[b]{2}{*}{$\mathrm{N}$ with data } & \multicolumn{4}{|c|}{ Percentage presenting late } \\
\hline & & & Overall & $(95 \% \mathrm{CI})$ & Non-acute $^{a}$ & Non-diab PRD \\
\hline \multirow[t]{6}{*}{$\mathrm{N}$ Ireland } & Antrim & 62 & 27.4 & $(17.8-39.8)$ & 22.2 & 30.2 \\
\hline & Belfast & 117 & 16.2 & $(10.6-24.1)$ & 10.3 & 18.0 \\
\hline & Derry & 35 & 17.1 & $(7.9-33.3)$ & 15.6 & 16.1 \\
\hline & Newry & 40 & 15.0 & $(6.9-29.6)$ & 10.8 & 14.3 \\
\hline & Tyrone & 29 & 3.5 & $(0.5-20.8)$ & 0.0 & 5.0 \\
\hline & Ulster & 33 & 27.3 & $(14.8-44.7)$ & 14.3 & 34.8 \\
\hline \multirow[t]{4}{*}{ Wales } & Bangor & 51 & 23.5 & $(13.9-37.0)$ & 22.0 & 29.0 \\
\hline & Cardff & 314 & 13.7 & $(10.3-18.0)$ & 11.3 & 16.9 \\
\hline & Swanse & 221 & 26.7 & $(21.3-32.9)$ & 20.1 & 27.3 \\
\hline & Wrexm & 41 & 14.6 & $(6.7-29.0)$ & 11.4 & 19.4 \\
\hline E, W \& NI & & 6,895 & 20.0 & $(19.1-21.0)$ & 15.2 & 22.9 \\
\hline
\end{tabular}

Blank cells = data for PRD not used

${ }^{a}$ Non-acute group excludes crescentic (extracapillary) glomerulonephritis (type I, II, III), nephropathy (interstitial) due to cis-platinum, renal vascular disease due to malignant hypertension, renal vascular disease due to polyarteritis, Wegener's granulomatosis, cryoglobulinemic glomerulonephritis, myelomatosis/light chain deposit disease, Goodpasture's Syndrome, systemic sclerosis (scleroderma), haemolytic ureaemic syndrome (including Moschcowitz syndrome), multi-system disease - other, tubular necrosis (irreversible) or cortical necrosis, Balkan nephropathy, kidney tumour, and traumatic or surgical loss of kidney

of patients presenting within $6-12$ months, $4.9 \%$ within 3-6 months and $20.6 \%$ within 3 months. Figure 1.11 shows this breakdown by year for those 13 centres supplying data for each of the last 6 years with $>75 \%$ completeness (Bradford, Dorset, Gloucester, Leeds, Middlesbrough, Nottingham, Oxford, Portsmouth, Sheffield, Stevenage, Swansea, Tyrone and Wolverhampton). The proportion of patients presenting late in these centres has steadily fallen since 2005 and there has been an increase in those presenting 12 months or more before starting RRT. These trends appear to have levelled off at the end of the six years.

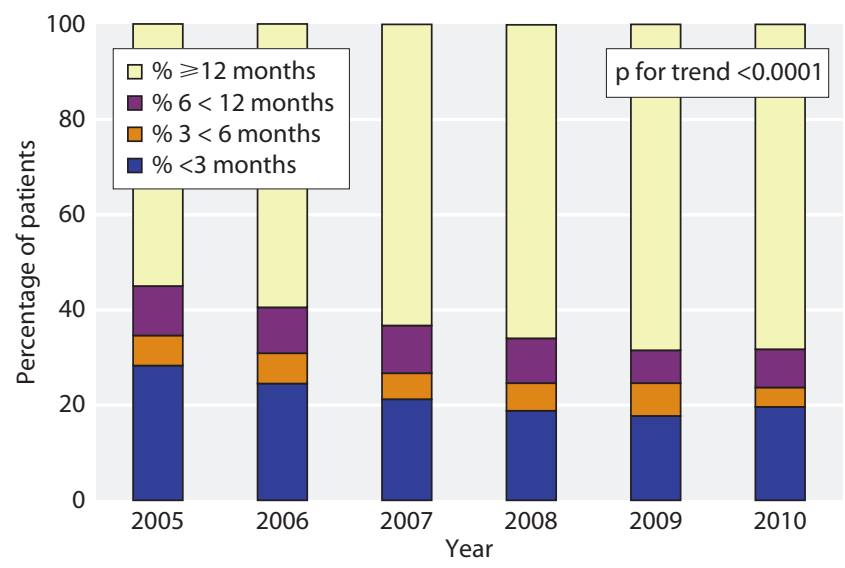

Fig. 1.11. Late presentation rate by year $2005-2010$ Restricted to centres reporting continuous data 2005-2010

\section{Age and late presentation}

In contrast to the results shown in last year's report, patients who presented late were not significantly older than patients who presented earlier ( $>90$ days before RRT initiation) (median age 65.6 vs. 65.4 years: $\mathrm{p}=0.5)$. The cohort used here was 2009 to 2010 whereas in last year's report it was 2004 to 2009 and so this change may have happened over the longer term than just 2009 to 2010. Also in contrast to the pattern shown in last year's report, the median duration of pre-RRT care did not diminish with increasing age beyond the 55-64 age group (figure 1.12).

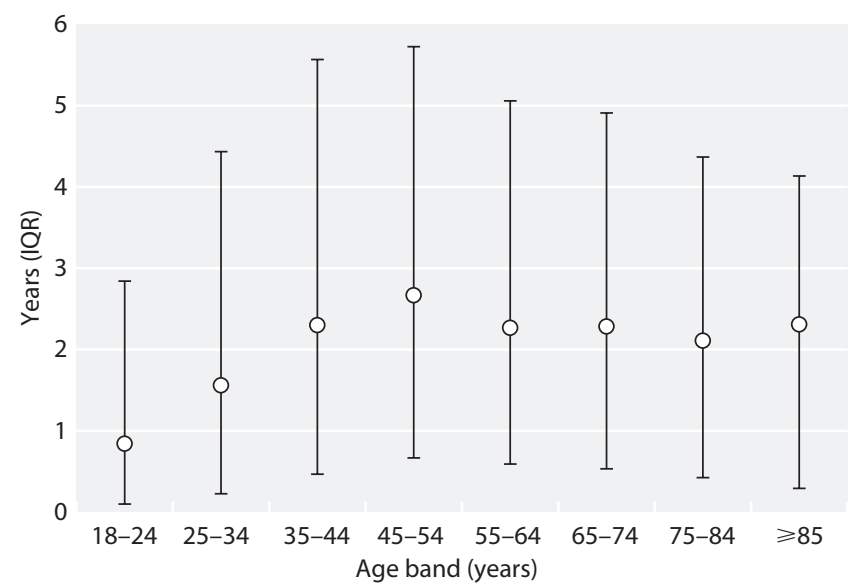

Fig. 1.12. Median duration of pre-RRT care by age group (20092010 incident patients) 
Table 1.13. Late presentation by primary renal diagnosis (20092010 incident patients)

\begin{tabular}{lrrr}
\hline & & \multicolumn{2}{c}{ Late presentation } \\
\cline { 3 - 4 } Diagnosis & $\mathrm{N}$ & $\mathrm{N}$ & $\%$ \\
\hline Uncertain aetiology & & & \\
\cline { 3 - 4 } & 1,290 & 278 & 21.6 \\
Diabetes & 1,501 & 144 & 9.6 \\
Glomerulonephritis & 691 & 104 & 15.1 \\
Other identified category & 517 & 123 & 23.8 \\
Polycystic kidney or & 931 & 93 & 10.0 \\
pyelonephritis & & & \\
Renal vascular disease & 826 & 131 & 15.9 \\
Acute group & 608 & 353 & 58.1 \\
Data not available & 393 & 120 & 30.5 \\
\end{tabular}

ancludes presumed glomerulonephritis not biopsy proven

Unlike elsewhere in the report the RVD group includes hypertension. Also, polycystic and pyelonephritis are grouped together

Acute group includes crescentic (extracapillary) glomerulonephritis (type I, II, III), nephropathy (interstitial) due to cis-platinum, renal vascular disease due to malignant hypertension, renal vascular disease due to polyarteritis, Wegener's granulomatosis, cryoglobulinemic glomerulonephritis, myelomatosis/light chain deposit disease, Goodpasture's Syndrome, systemic sclerosis (scleroderma), haemolytic ureaemic syndrome (including Moschcowitz syndrome), multisystem disease-other, tubular necrosis (irreversible) or cortical necrosis, Balkan nephropathy, kidney tumour, and traumatic or surgical loss of kidney

\section{Gender and late presentation}

There was no significant difference in the proportion of males to females by time of presentation (male:female ratio 1.66 in early presentation, 1.84 in late presentation, $\mathrm{p}=0.12)$.

\section{Ethnicity, social deprivation and late presentation}

This analysis of the 2009 to 2010 cohort was limited to patients from centres/years with $>70 \%$ ethnicity and $>75 \%$ presentation time data. Patients from the Chinese and Other ethnic minority groups were excluded due to the small numbers with presentation data. The percentage of non-Whites (South Asian and Black) presenting late ( $<90$ days) was lower than in Whites but not significantly so $(17.4 \%$ vs. $20.0 \%$ : $\mathrm{p}=0.06)$. The high incidence of diabetes in non-Whites (as discussed below, patients with diabetes tended to present earlier) may explain this difference. There was no relationship between social deprivation and presentation pattern.

\section{Primary renal disease and late presentation}

In the 2009 to 2010 cohort, late presentation differed significantly between primary renal diagnoses (Chisquared test $\mathrm{p}<0.0001$ ) (table 1.13). Patients in the acute group or with data 'not available' had high rates
Table 1.14. Percentage prevalence of specific comorbidities amongst patients presenting late $(<3$ months) compared with those presenting early ( $\geqslant 3$ months) (2009-2010 incident patients)

\begin{tabular}{lccc}
\hline Comorbidity & $<3$ months & $\geqslant 3$ months & p-value \\
\hline Cerebrovascular disease & 6.3 & 11.5 & $<0.0001$ \\
COPD & 7.5 & 8.1 & 0.6 \\
Diabetes (not a cause of & 7.0 & 9.4 & 0.03 \\
ERF) & & & \\
Ischaemic heart disease & 16.9 & 23.0 & 0.0002 \\
Liver disease & 3.6 & 2.6 & 0.12 \\
$\begin{array}{l}\text { Malignancy } \\
\text { Peripheral vascular }\end{array}$ & 19.9 & 11.9 & $<0.0001$ \\
disease & 10.0 & 12.4 & 0.07 \\
Smoking & & & \\
\hline
\end{tabular}

of late presentation. Those with diabetes and pyelonephritis or adult polycystic kidney disease had low rates. Since 2005 there has been a significant decline in the proportion of diabetics presenting late (MantelHaenszel Chi-squared test $p=0.002$ ) although this has levelled off in recent years. The decline seen likely reflects national initiatives to screen patients with diabetes for proteinuria and falling GFR.

\section{Modality and late presentation}

In the 2009 to 2010 cohort, late presentation was associated with initial modality. The percentage of patients whose first modality was PD was significantly lower in the late presentation group compared to those presenting earlier $(9.6 \%$ vs. $21.8 \%$ : $\mathrm{p}<0.0001)$. By 90 days after RRT initiation this difference was reduced, although still highly significant $(12.9 \%$ vs. $22.2 \%$ : $\mathrm{p}<0.0001)$.

\section{Comorbidity and late presentation}

In the 2009 to 2010 cohort, the percentage of patients who were assessed as having no comorbidity was roughly the same in those who presented late and those presenting earlier $(45.7 \%$ vs. $44.2 \%: \mathrm{p}=0.4)$. This is in contrast to the 2004-2009 analysis published last year which showed the percentage with no comorbidity to be slightly, but significantly, lower in patients who presented late. Cerebrovascular disease, ischaemic heart disease and diabetes were significantly less common in the group presenting late (table 1.14). Malignancy was significantly more common in those presenting late, perhaps because of the potential for rapid decline in renal function in this group. 


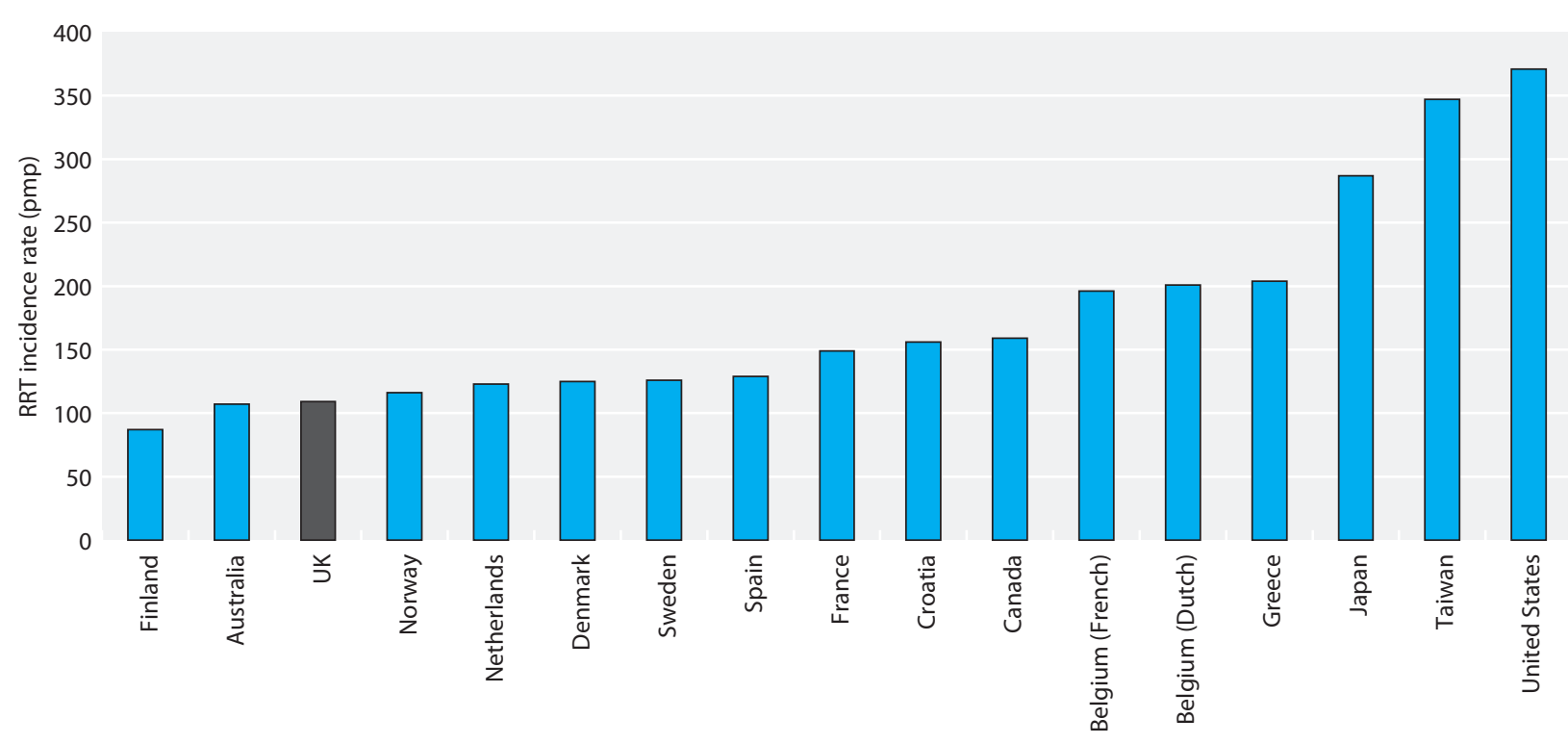

Fig. 1.13. International comparison of RRT incidence rates in 2009 Data from USRDS

\section{Haemoglobin and late presentation}

In the 2009 to 2010 cohort, patients presenting late had a significantly lower haemoglobin concentration at RRT initiation than patients presenting earlier ( 9.3 vs. $10.4 \mathrm{~g} / \mathrm{dl}: \mathrm{p}<0.0001)$. This may reflect inadequate predialysis care with limited anaemia management, but alternatively those presenting late may be more likely to have anaemia because of multisystem disease or inter-current illness.

\section{eGFR at start of RRT and late presentation}

In the 2009 to 2010 cohort, eGFR at start of RRT was lower in patients presenting late $(7.8$ vs. $8.8 \mathrm{ml} / \mathrm{min} /$ $\left.1.73 \mathrm{~m}^{2}: \mathrm{p}<0.0001\right)$.

\section{Survival of incident patients}

This analysis is to be found in chapter 6: Survival and Causes of Death of UK Adult Patients on Renal Replacement Therapy in 2010.

\section{International comparisons}

Figure 1.13 shows the crude RRT incidence rates for 2009 for several countries. The UK incidence rate is similar to many other Northern European countries and Australia, but remains lower than Belgium, Greece, US,
Japan and Taiwan. These differences are likely to be due to the rate of advanced kidney disease in these populations as well as lower mortality from competing risks for RRT, such as cardiovascular disease in southern Europe and the Far East. The healthcare system in use in these countries may also influence RRT incidence.

\section{Summary}

RRT incidence rates for 2010 were similar to 2009 for England and for the UK as a whole. At least partly because of the smaller numbers involved they have been more variable over the last few years for Northern Ireland, Scotland and Wales. Wales continues to have the highest incidence rate. There remain large centre variations in incidence rates for RRT. Significant numbers of patients continue to present late to renal centres.

Conflicts of interest: none

\section{Acknowledgements}

The Registry would like to acknowledge the significant contribution made by Andy Judge, Dan Ford, David Ansell, Charlie Tomson, Paul Roderick and Yoav Ben-Shlomo who developed the methodology for estimating catchment populations for England. 


\section{References}

1 Office for National Statistics. www.ons.gov.uk

2 Office for National Statistics. The classification of ethnic groups. http:// www.ons.gov.uk/ons/guide-method/classifications/archived-standardclassifications/ethnic-group-interim-classification-for-2001/index.html

3 Levey AS, Bosch JP, Lewis JB, Greene T, Rogers N, Roth D. A more accurate method to estimate glomerular filtration rate from serum creatinine: a new prediction equation. Modification of Diet in Renal Disease Study Group. Ann Intern Med 1999;130:461-70

4 http://www.ons.gov.uk/ons/rel/ethnicity/focus-on-ethnicity-andidentity/focus-on-ethnicity-and-identity-summary-report/focus-onethnicity-and-identity-summary-report.pdf
5 Ford DJ, Fogarty DG, Steenkamp R, Tomson CRV, Ben-Shlomo Y, Ansell D. Chapter 13: The UK Renal Registry Advanced CKD Study: frequency of incorrect reporting of date of start of RRT. Nephron Clinical Practice; 115(Suppl. 1):c271-c78

6 U.S. Renal Data System, USRDS 2011 Annual Data Report: Atlas of Chronic Kidney Disease and End-Stage Renal Disease in the United States, National Institutes of Health, National Institute of Diabetes and Digestive and Kidney Diseases, Bethesda, MD, 2011. Publications based upon USRDS data reported here or supplied upon request must include this citation and the following notice: The data reported here have been supplied by the United States Renal Data System (USRDS)

7 http://www.renal.org/CKDguide/full/UKCKDfull.pdf 